\title{
ARTICLES
}

\section{THE EARNED INCOME TAX CREDIT AND THE LIMITATIONS OF TAX-BASED WELFARE REFORM}

\author{
Anne L. Alstott*
}

\begin{abstract}
The earned income tax credit (EITC), which uses the federal income tax system to provide an earnings subsidy to low-income workers, has enjoyed support across the political spectrum as a "pro-work, pro-family" alternative to traditional welfare programs. Advocates of the EITC also claim that the EITC's tax-based administration is cheaper and less stigmatizing than traditional welfare administration. In this Article, Professor Alstott argues that the case for the EITC has been oversimplified in two significant ways. First, the Article argues that both advocates and opponents of the EITC place undue emphasis on whether it discourages work and marriage among EITC recipients. Professor Alstott demonstrates that the conventional policy debate over the EITC's behavioral incentives is too narrowly framed: the debate relies on incomplete economic analysis and reflects important but unacknowledged normative tensions. Second, the Article shows that the EITC, as a tax-based income-transfer program, faces inherent institutional constraints not present in traditional welfare programs. Professor Alstott explains that, although economists and policy analysts have long advocated integration of the tax and transfer systems, they have overlooked the problems of inaccuracy, unresponsiveness, and noncompliance that are inherent in tax-based administration. The Article goes on to demonstrate that, although reforms might improve the EITC's performance along these dimensions, such improvements would require either compromising the benefits of tax-based administration or undertaking a major restructuring of basic institutions of the federal tax system. Professor Alstott concludes that, absent such changes, the EITC and similar tax-based transfers are likely to prove widely acceptable only if we radically revise our expectations about accuracy, responsiveness, and compliance.
\end{abstract}

\section{INTRODUCTION}

$\mathrm{T}$ he federal earned income tax credit (EITC), which provides cash payments to low-income workers, has recently assumed a central role in U.S. social welfare policy. Under legislation enacted in $1993,{ }^{1}$ by 1997 the EITC will pay annual aggregate benefits as large as those paid under Aid to Families with Dependent Children (AFDC), the na-

* Associate Professor, Columbia University School of Law. I owe special thanks to Marvin Chirelstein, Michael Graetz, and Al Warren for their wise and patient comments on numerous drafts. I also received very helpful comments from Mark Barenberg, Alan Feld, Jeff Gordon, Joel Handler, Glenn Hubbard, Louis Kaplow, Bill Klein, Jeff Liebman, Lance Liebman, Ed McCaffery, Subha Narasimhan, Dick Pierce, Dan Shaviro, George Yin, and the participants in the I993 Harvard Seminar on Current Research in Taxation. Antonio Peguero and Stefanie Niebisch provided important research assistance, and the Columbia Law School alumni fund provided financial support.

1 Omnibus Budget Reconciliation Act of 1993, Pub. L. No. 103-66, § 13131, 107 Stat. 312, 433-35 (I993) (codified at I.R.C. § 32 (I988 \& Supp. V I993)). 
tion's principal cash welfare program. ${ }^{2}$ The I993 expansion of the EITC is a key feature of President Clinton's plan for welfare reform. ${ }^{3}$

Although the EITC is styled a "refundable tax credit," in fact it is a kind of welfare program - or, in economists' terms, an incometransfer program. It uses the rules and procedures of the federal income tax system to make payments to low-income workers based on their earnings and total income. As a refundable tax credit, the EITC not only reduces or eliminates federal income tax liability, but also pays cash to low-income taxpayers whose EITC exceeds the tax they owe. $^{4}$

For many years, the EITC was a relatively small program, viewed principally as a means of offsetting the adverse distributional and incentive effects of federal income and payroll taxes on low-income workers. In recent years, however, the EITC's advocates have increasingly promoted the EITC as a solution to two central and recurring concerns of welfare policy. First, proponents claim, the EITC promotes work and family responsibility among the poor, unlike traditional welfare programs, which have long attracted criticism for their putative effects on work and family structure. Second, advocates argue, because the EITC is part of the federal tax system, it is simpler and cheaper to administer than programs run by the welfare bureaucracy and affords greater dignity and privacy to beneficiaries.

A close examination of the two central claims made for the EITC reveals that the EITC is neither the radical departure from welfare that its advocates claim, nor the duplicate of welfare that its opponents depict. In this Article, I argue that current debates over the EITC are seriously incomplete in two ways. First, both advocates and opponents of the program give undue weight to its potential effects on work and marriage among EITC recipients. The EITC's advocates exaggerate the program's effectiveness in encouraging work. Opponents emphasize the program's potential work disincentives, arguing that the EITC is welfare all over again. This conventional debate is too narrowly framed. It relies on an incomplete economic analysis and reflects important but unacknowledged normative tensions. Debates over the EITC's effects on marriage are also flawed: they typically

2 For fiscal year 1997 , the projected total benefits to be paid under the EITC are $\$ 25.4$ billion, and projected total federal and state benefits to be paid under AFDC are just under $\$ 24.8$ billion, exclusive of administrative costs. See House Comm. on Ways AND MEANS, 103D Cong., 2D Sess., Overview of Entitlement Programs: 1994 Green Book 389, 678 (Comm. Print I994) [hereinafter 1994 GREEN BOOK].

3 See Transcript of President Clinton's Message on the State of the Union, N.Y. TIMEs, Jan. 26, I994, at AI6 [hereinafter State of the Union].

4 EITC recipients receive cash to the extent that their EITC benefit exceeds the federal income tax they owe. The bulk of EITC benefits are paid in cash. About $\$ 2$ I.3 billion of the $\$ 25.4$ billion in projected EITC benefits for fiscal year 1997, for example, will be cash payments rather than offsets to federal income taxes. See 1994 GREEN BooK, supra note 2, at 678 . 
lack empirical foundation and ignore important realities of institutional design.

Second, both proponents and opponents of the EITC have overlooked the important point that, because the EITC is a tax-based transfer program, it faces significant institutional constraints that are not present in traditional welfare programs. Tax-based transfer programs may be cheaper and less stigmatizing than welfare, although advocates typically assert these claims without empirical support. Nevertheless, this Article shows that the tax system's limitations render the EITC inherently inaccurate, unresponsive, and vulnerable to fraud and error in ways that traditional welfare programs are not. More empirical evidence is needed to evaluate the magnitude of these structural flaws and to make a quantitative comparison of tax-based and traditional programs. The central point, however, is that improving the performance of the EITC or other tax-based transfer programs requires either compromising the benefits of tax-based administration or undertaking a major restructuring of basic institutions of the federal tax system. Absent large-scale (and politically unlikely) reform of the federal income tax, the EITC and similar tax-based transfer programs are likely to prove acceptable only if we radically revise our expectations about accuracy, responsiveness, and compliance in income-transfer programs. ${ }^{5}$

This second point is particularly important because the prospect of a unified tax-transfer system has fascinated economists and other public policy analysts at least since discussions of the negative income tax in the $1960{ }^{6}{ }^{6}$ This Article challenges the simple case for integrating the tax and transfer systems by showing the institutional dilemmas inherent in such an approach. Ultimately, this analysis suggests greater tolerance of separate tax and transfer systems. Although the different rules of the tax and welfare systems reflect a complex set of political choices made over time, at least some of the existing institutional variations permit the two systems to tailor their administrative structures to emphasize different policy objectives, and that flexibility would be compromised in an integrated tax and transfer system. A more sophis-

5 This Article builds on important scholarship from the r 960 and early r 970 os on administration of the negative income tax. See infra note 130. Those scholars concentrated principally on devising concrete rules and procedures to minimize problems of accuracy and responsiveness in the negative income tax standing alone. This Article shows how similar concerns arise in administering the EITC, which differs in significant ways from the negative income tax. Further, this Article argues that the EITC illustrates a basic dilemma of tax-transfer integration: reforms intended to improve accuracy, responsiveness, or compliance necessarily conflict with the goals of tax-transfer integration.

6 See, e.g., Milton Friedman, Capitalism and Freedom igi-93 (ig62); Christopher Green, Negative Taxes and the Poverty Problem i60-76 (I967). 
ticated approach to tax-transfer integration would consider alternative ways to combine the separate strengths of the two systems. ${ }^{7}$

This Article uses a study of the EITC to illustrate some of the core dilemmas of income redistribution through tax-based transfer programs. It is the first step in my larger project of elaborating a legal policy framework for comparing and evaluating alternative incometransfer policies, both within and outside the tax system. My analysis seeks to situate tax-based transfer programs in the appropriate context - as one of many alternatives for implementing social welfare policy. The central task of the project is to examine carefully the institutional characteristics of tax-based transfers, in order to identify the inevitable trade offs in institutional design that require difficult compromises among competing goals and, ultimately, to develop a normative framework for determining how those compromises can best be made.

\section{The Case for the eitc as Welfare Reform}

In one respect, the EITC represents an important liberalization of American social welfare policy. The EITC embodies a recognition that hard work may not lift a family out of poverty when wages are low and that the working poor as well as the nonworking poor need and deserve income transfers to support their families. ${ }^{8}$ Traditional welfare programs provide little aid to the working poor. Categorical eligibility restrictions exclude many families, and high benefit reduction rates quickly deny benefits even to workers with low earnings. ${ }^{9}$ In contrast, the EITC has grown in recent years to provide substantial levels of assistance to the working poor. ${ }^{10}$ Table 1 documents the EITC's growth since its enactment in 1975 .

7 This Article seeks to point out some of the shortcomings in conventional comparisons between the EITC and alternative programs, but providing a comprehensive comparative evaluation of alternative programs is beyond the scope of this Article.

8 See, e.g., David T. Ellwood, Poor Support 8i-io4 (ig88); Isaac Shapiro \& Robert Greenstein, Center on Budget and Policy Priorities, Making Work Pay: The UnfinISHED AGENDA 3-I7 (1993). In I99 I, 9.2 million workers (2.I million of whom worked full-time, year round) were poor under the official federal definition of poverty, and 5.5 million people were members of poor families with children that included a full-time, year-round worker. See U.S. Dep't of Health and Human Servs., Brief Overview of EITC, Aug. 19, I993 (press release), reproduced in 93 TAX Notes TOdAy 174-120, Aug. 20, 1993, available in LEXIS, Fedtax Library, Taxtxt File. For a striking anecdotal account of economic hardship among the working poor, see Tony Horwitz, The Working Poor: Minimum-Wage Jobs Give Many Americans Only a Miserable Life, Wall St. J., Nov. I2, I993, at AI.

9 See Sar A. Levitan \& IsaAC Shapiro, Working But Poor 98-106 (1987).

10 By calendar year I996, the EITC will provide tax credits or cash benefits of up to $\$ 3370$ per year in 1994 dollars. See I.R.C. $\S 32$ (b) (Supp. V I 993) (providing for a "credit percentage" of $40 \%$ and a maximum "earned income amount" of \$8425). About 2 I million families are expected to be eligible for the credit in 1996. See Congressional Budget Office, An Economic ANALysis of THE Revenue Provisions of OBRA-93, at 8-10 (I994) [hereinafter CBO]. The program's total annual cost in fiscal year 1997 will exceed \$25 billion, see 1994 GREEN BoOK, supra note 2 , at 678 , which will be approximately 13 times the (nominal-dollar) I 986 cost of the pro- 
Table 1: The Expansion of the EITC, 1975-1995

$\begin{array}{cccc}\text { Year } & \begin{array}{c}\text { Earnings } \\ \text { Subsidy Rate }\end{array} & \begin{array}{c}\text { Maximum } \\ \text { Credit }\end{array} & \begin{array}{c}\text { Income } \\ \text { Cutoff }\end{array} \\ 1975 & 10 \% & \$ 400 & \$ 8,000 \\ 1980 & 10 \% & \$ 500 & \$ 10,000 \\ 1985 & 11 \% & \$ 550 & \$ 11,000 \\ 1988 & 14 \% & \$ 874 & \$ 18,576 \\ 1994 & 30 \% & \$ 2528 & \$ 25,300 \\ 1996^{*} & 40 \% & \$ 3370 & \$ 27,000\end{array}$

Source: 1994 GREEN BooK, supra note 2, at 700 (giving EITC for families with two or more children).

* The I 996 figures show the fully-phased-in effects of the 1993 amendments to the EITC. All figures are in nominal dollars, except that the EITC benefit and income cutoff for 1996 are stated in 1994 dollars. See infra notes 33-39 and accompanying text.

The case for the EITC, however, reflects the uneasy state of current welfare politics, in which the EITC's redistributive function is cloaked in anti-welfare rhetoric to attract maximum political support. ${ }^{11}$ This strategy could potentially turn anti-welfare sentiment to political advantage, but it is also risky. Promoting the EITC as the answer to the problems of welfare feeds inflated expectations about the capabilities of redistributive programs and reinforces negative attitudes about welfare that, in the long run, may jeopardize the cause of the EITC and of poverty relief more generally. Recent attacks on the EITC that condemn it as "welfare" and as a "handout" suggest that this danger is more than theoretical. ${ }^{12}$

Thus far, the EITC has found a secure niche in welfare policy by responding to two strong themes in current debates: a bipartisan consensus on work-based welfare reform and widespread dissatisfaction with traditional welfare administration. One familiar critique of welfare is that it allows and encourages recipients to violate important norms of individual responsibility. Critics argue that, by providing a guaranteed minimum income and sharply reducing benefits in response to any earnings, the welfare system discourages work and marriage and prevents the poor from accumulating the work experience

gram, see House Comm. on Ways and Means, 103d Cong., 1St Sess., Overview of Entitlement Programs: 1993 Green Book ro58 (Comm. Print 1993) [hereinafter 1993 Green Book].

11 See infra p. 539. A similar strategy linking work and benefits underlies the success of Social Security. Social Security's redistributive effects have been obscured by the promotion of the program as one in which each person gets only the benefits he or she has "earned." See JoEL F. Handler \& Yeheskel Hasenfeld, The Moral Construction of Poverty 97-100 (I991); C. Eugene Steuerle \& Jon M. Bakija, Retooling Social Security for the 21st CenTURY 23 (1994).

12 See James Bovard, Clinton's Biggest Welfare Fraud, Wall ST. J., May 10, I994, at Ar8; see also Paul C. Roberts, Revenge of the Unheards ... Rising; Clinton's Deception, WASH. Times, May 27, 1993, at G I (calling the EITC "a program that pays taxpayer dollars to people who don't even earn enough to be taxpayers"). 
that would improve their prospects over the long term. ${ }^{13}$ Another common criticism is that the current welfare system is miserly, stigmatizing, and uneven in coverage - that it rewards the "dependent" poor but provides too little assistance to the working poor. ${ }^{14}$ These views reflect widely varying normative premises and support different policy prescriptions. Dismantling or reducing the size of the welfare system is one option; ${ }^{15}$ another is to continue to provide welfare but with strict work requirements; ${ }^{16}$ still another is to expand the government's role in job training and, if necessary, to provide guaranteed jobs to the poor. ${ }^{17}$ Nevertheless, there is an apparent political consensus in support of reforms that in some way link welfare and work. ${ }^{18}$ The Family Support Act of $1988,{ }^{19}$ which mandates job-training programs intended to increase work among welfare recipients, reflects this consensus. ${ }^{20}$ The Clinton administration's 1994 proposals, which would transform welfare gradually into a program of mandatory work, evoke similar themes. ${ }^{21}$

13 See generally Lawrence M. MEAd, Beyond Entitlement 4 (I986) (arguing that welfare recipients should be required to work to encourage them to "function"); LAWRENCE M. MEAD, The New Politics of Poverty I3 (I992) [hereinafter Mead, New Politics] (arguing that work is essential to enable the poor to become "functioning citizens"); CHARLES MURRAY, Losing GROUND I54-66 (I984) (arguing that increases in welfare benefits from I960 to I970 discouraged work and marriage). For critiques of Mead's and Murray's works, see Christopher JENCKS, Rethinking Social Policy 70-9i (i992); Michael B. Katz, The Undeserving Poor i57-65 (i 989); William J. Wilson, The Truly Disadvantaged i59-63 (I987); and Sara McLanahan, Glen Cain, Michael Olneck, Irving Piliavin, Sheldon Danziger \& Peter Gottschalk, Are We Losing Ground?, Focus, Fall \& Winter 1985, at I, I-I2. Joel Handler and Yeheskel Hasenfeld argue that work has always been of central importance in American welfare policy's moral distinction between the deserving and undeserving poor. See HANDLER \& HASENFEld, supra note I I, at i6.

14 See Ellwood, supra note 8, at 25, 98-104.

15 See, e.g., MURRAY, supra note 13 , at 25, 98-104.

16 See, e.g., MEAD, NEw Politics, supra note 13 , at i66-84.

17 See, e.g., Ellwood, supra note 8, at 238. For richer evaluations of the current welfare debate, consult HANDLER \& HASENFELD, cited above in note I I, at I 70-200, 230-4I; KATZ, cited above in note $\mathrm{I}_{3}$, at 3-8, 236-39; and Frances F. Piven \& Richard A. Cloward, The Contemporary Relief Debate, in The Mean Season: The Attack on the Welfare State 45, 92-ioi (Fred Block, Richard A. Cloward, Barbara Ehrenreich \& Frances F. Piven eds., 1987).

18 See, e.g., Sheldon Danziger, Fighting Poverty and Reducing Welfare Dependency, in WELFARE POlicy FOR THE 1990S, at 4I, 4I-42 (Phoebe H. Cottingham \& David T. Ellwood eds., 1989). However, this consensus is not seamless. See Joel F. Handler, The Transformation of Aid to Families with Dependent Children: The Family Support Act in Historical Context, I6 N.Y.U. Rev. L. \& Soc. Change 457, 516-18 (1987-88).

19 Family Support Act of 1988, Pub. L. No. 100-485, § 201, 102 Stat. 2343, 2356-60 (1988) (codified at 42 U.S.C. $\$ 602$ (1988)); 1994 GREEN BoOK, supra note 2, at 337-59.

20 See Handler, supra note 18 , at $458-59$.

21 Very generally, the Clinton program would limit welfare receipt to two years. See S. 2224 , I03d Cong., 2d Sess. § 104, reprinted in 140 CoNG. REc. S7274 (daily ed. June 21 , I994); 140 CoNG. REC. $\mathrm{S}_{7322}$ (explaining the time limit). During that period, welfare recipients would participate in government-funded programs including education, job training, and job search. See S. 2224 , supra, \& 102, reprinted in I40 CONG. REc. S7274 (daily ed. June 21 , 1994); I40 Cong. REC. S7323-24 (outlining these programs). At the end of that period, welfare recipients would be expected to work, and those recipients who could not find employment on their own would be 
In the current political climate, then, work and responsibility are "in" and traditional welfare is "out." It may appear to those committed to providing public assistance that there is little to lose - and much to gain for the poor - by promoting the EITC as the "pro work" and "pro family"22 solution to welfare's perceived disincentives and administrative failures. David Ellwood, formerly of Harvard's Kennedy School of Government and now Assistant Secretary of the Department of Health and Human Services, described the EITC this way:

The EITC helps the working poor while mainly avoiding the conundrums [of welfare]. The rewards of work are increased, not diminished. . . People are helped without any need of a stigmatizing, invasive, and often degrading welfare system, and their autonomy is increased, not decreased. Since it truly would be part of the tax system (unlike the badly named negative income tax, which really was welfare all over again), people would not be isolated. ${ }^{23}$

Political speeches advocating the EITC also adopt a strong anti-welfare theme. In his 1994 State of the Union message, for example, President Clinton argued that the 1993 expansion of the EITC "reward[s] work over welfare ... . Now that's real welfare reform."24 Congressional proponents of the program emphasized in 1993 that the EITC "is the furthest thing from a handout" 25 and "is not welfare, by any means." 26

Some commentators oppose work requirements in welfare programs on the grounds that mandatory work (or "workfare") programs are more expensive, less effective, and harsher than voluntary work

provided a guaranteed job. See S. 2224, supra, § 20I, reprinted in I40 CONG. REc. S7275-77 (daily ed. June 2I, I994); I40 CONG. REC. S7326-27 (explaining the work guarantee facet). The plan relies on the EITC to supplement the wages of low-income workers other than those who hold government-provided jobs. See S. 2224, supra, \$207, reprinted in I $_{40}$ CONG. REC. S728I (daily ed. June 21, I994); 140 CONG. REC. S7319 (noting the interaction between the EITC and the welfare reform proposal). The Clinton plan is similar to David Ellwood's proposals in Poor Support. See EllwOOD, supra note 8, at 238. Republican proposals to limit or eliminate welfare also emphasize work for welfare recipients. See Jason DeParle, Momentum Builds for Cutting Back Welfare System, N.Y. Times, Nov. I3, I994, at I.

22 This was a favorite slogan of EITC supporters during debates over the 1993 budget legislation that expanded the EITC. See, e.g., I39 CONG. REC. H5532 (daily ed. July 30, I993) (statement of Rep. Richardson) ("[T]he EITC is pro-work because, unlike other forms of assistance to the poor, only those who work and have earnings can receive benefits. . . The EITC is profamily because it is available only to families that stay with their children and their [sic] is no discrimination against two-parent families."); see also SHAPIRO \& GREENSTEIN, supra note 8, at vii ("The EITC is often described as 'pro-work' and 'pro-family.").

23 Ellwood, supra note 8, at II5.

${ }^{24}$ State of the Union, supra note 3 , at Ai6.

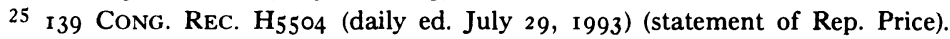

${ }_{26}$ Id . at $\mathrm{H}_{5503}$ (daily ed. July 29, I993) (statement of Rep. Wise). Similar themes have been evident throughout the EITC's history. See, e.g., H.R. REP. No. 1445, 95 th Cong., 2d Sess. 39 (1978); S. REP. No. 938, 94th Cong., 2d Sess. 119 (1976), reprinted in 1976 U.S.C.C.A.N. 3439,

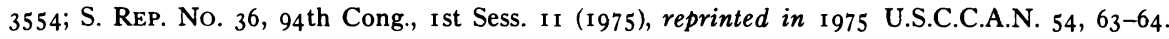


programs. ${ }^{27}$ But the EITC, unlike workfare, has no mandatory work feature. It provides income transfers to people who choose to work, and it does not deny current welfare benefits to nonworkers. Thus, some opponents of mandatory work requirements in welfare programs do not criticize the EITC. ${ }^{28}$ The EITC has also garnered additional political support as a program of tax relief $^{29}$ and even child care, ${ }^{30}$ which appeal to political constituencies that may not be concerned with welfare reform per se.

How does the EITC achieve its ostensible advantages over welfare? The EITC is a complex hybrid of an earnings subsidy, a traditional income-transfer program, and a tax credit program. ${ }^{31}$ Understanding these features and the tensions they create lays the groundwork for the subsequent analysis of the EITC's effects on behavior and its institutional limitations.

Traditional income transfers provide a useful benchmark for comprehending the EITC. A traditional income-transfer program that tailors benefits to need pays the largest benefits to families with the lowest incomes and reduces benefits as income rises. Thus, a family

27 See HANDlER \& HASENFEld, supra note II, at $23 \mathrm{I}$.

28 See id. at $159-60$.

29 Between 1975 and 1986, the EITC's role as an offset to the economic burden on lowincome workers of the growing Social Security payroll tax helped to justify several increases in the credit. See S. Rep. No. 313, 99th Cong., 2d Sess. 43 (1986); S. Rep. No. 938, 94th Cong., 2d Sess. II9 (1976), reprinted in 1976 U.S.C.C.A.N. 3439, 3554; H.R. REP. No. 19, 94th Cong., Ist Sess. 29 (1975). In the early I9gos, deficit reduction legislation relied on expansions of the EITC to head off opposition to regressive tax increases. See C. Eugene Steuerde, The Tax Decade I 78-79 (1992); cf. Selected Aspects of Welfare Reform: Hearings Before the Subcomm. on Select Revenue Measures and Subcomm. on Human Resources of the House Comm. of Ways and Means, I03d Cong., Ist Sess. I9 (1993) [hereinafter 1993 Welfare Reform Hearings] (statement of Samuel Y. Sessions, Deputy Assistant Secretary (Tax Policy), Dep't of the Treasury) (noting that a proposed increase in the EITC would help offset the impact on low income families of a proposed energy tax). Changes in the tax law, but not in transfer programs, are taken into account in determining the distributional effect of a tax bill. See StafF of THE Jornt Comm. ON TAXAtion, 103d Cong., 1st Sess., Methodology and Issues in Measuring Changes in the DisTRIBUtion OF TAX BURdens 2 (Comm. Print I993). This convention may enhance the EITC's political appeal, because an EITC increase appears in the distribution tables as an offset to regressive tax increases, but an increase in AFDC benefits, for example, does not.

30 In the late I980s and early I9gos, the Bush administration promoted an increase in the EITC as a way to finance child care for low-income workers. See Statement on Proposed ChildCare Legislation, I PUB. PAPERS 240-4I (1989). Members of Congress also touted the EITC as a program that eased the burden of child care. See I35 Cong. REc. E3387 (daily ed. Oct. II, 1989) (statement of Rep. Kolbe); id. at $\mathrm{H}_{3950}$ (daily ed. July 20, 1989) (statement of Rep. Petri).

31 In 1969, the Nixon administration proposed a negative income tax, the Family Assistance Plan (FAP). See H.R. I4I73, 91 st Cong., Ist Sess. (I 969). Congressional concern about the potential work disincentive effect of such a program helped defeat the bill. See Daniel P. Moynihan, The Politics of a Guaranteed InCOME 458-83 (I973). These concerns helped to motivate the EITC's hybrid earnings-subsidy/income-transfer structure. See S. REP. No. 36, 94th Cong., Ist Sess. I I (1975), reprinted in 1975 U.S.C.C.A.N. 54, 63-64. The EITC was introduced as a "work bonus program" in 1972. H.R. I, 92d Cong., Ist Sess. $\$ 534$ (197 I). It was enacted in 1975. See Tax Reduction Act of 1975 , Pub. L. No. 94-12, § 204, 89 Stat. 26, 30-32 (I975) (codified as amended at I.R.C. $\$ 32$ (1988 \& Supp. V I993)). 
with $\$ 5000$ of outside income typically receives smaller income-transfer benefits than a family of the same size with no outside income. As outside income increases, benefits fall, and at some level of income the income cutoff point - benefits fall to zero. ${ }^{32}$ The reduction in benefits as income rises can be termed the "income test."

The EITC produces a pattern of benefits that at first seems entirely different. ${ }^{33}$ For workers with earnings and total income between one dollar and $\$ 8425$, the EITC provides an earnings subsidy equal to an extra forty cents for every dollar of earnings. ${ }^{34}$ In this income range, the EITC appears to be a "backwards" income-transfer program, because it provides greater dollar benefits to those with higher earnings and no benefits at all to those without wages, regardless of need.

The EITC begins to tailor benefits to need through an income test at slightly higher levels of earnings. When earnings reach $\$ 8425$, the earnings subsidy is capped. ${ }^{35}$ Above that threshold, the dollar amount of EITC benefits remains constant up to an earnings level of $\$ 1 \mathrm{I}, 000^{36}$ and then is reduced by twenty-one cents for every dollar of earnings over $\$$ II, $000 . .^{37}$ Under this schedule, EITC benefits are reduced to zero at $\$ 27,000$ of earnings. ${ }^{38}$ Thus, between $\$ 11,000$ and $\$ 27,000$ in earnings, the EITC resembles a traditional income-transfer program, which reduces benefits as earnings increase. Table 2 and Graph 1 illustrate the EITC's distinctive, pyramidal pattern of benefits for a worker with two children. Initially, an increase in earnings results in higher EITC benefits; as earnings increase above $\$ 8425$, however, the EITC benefit first remains constant and then declines, ultimately to zero. $^{39}$

32 See 1994 Green Book, supra note 2, at 214-15, 324-25, 327-29, 757.

33 Throughout the Article, unless otherwise stated, all EITC parameters apply to families with two or more children. The EITC provides these recipients with the greatest earnings subsidy; workers with only one child receive a somewhat smaller subsidy, and single workers receive a much lower benefit. See I.R.C. $\$ 32$ (b) (Supp. V I993). In addition, because the I993 legislation phases in changes to the EITC between I994 and I996, see id., EITC parameters in the text are those that apply for calendar year 1996, expressed in 1994 dollars.

34 See id. $\$ 32$ (b)(r)(A) (Supp. V r 993 ).

35 See id. $\$ 32(\mathrm{a})(\mathrm{I}),(\mathrm{b})(2)(\mathrm{A})$ (Supp. V I 993$)$.

36 See id. $\$ 32(\mathrm{a})(2),(\mathrm{b})(2)(\mathrm{A})$ (Supp. V r 994$)$.

37 See id. $\$ 32(\mathrm{a})(2),(\mathrm{b})(\mathrm{r})(\mathrm{A}),(\mathrm{b})(2)(\mathrm{A})$ (Supp. V 1993).

38 At earnings of $\$ 27,000$, the benefit calculated under $\$ 3^{2}$ (a) and (b) is zero, because $(.4 x$ $\$ 8425)-[.2106 \times(\$ 27,000-\$ 11,000)]=0$. To prevent families with low earnings but significant unearned income from claiming the EITC, the reduction in benefits is based on the higher of earned income or adjusted gross income. See id. $\$ 32(\mathrm{a})(2)(\mathrm{B})$ ( 1988$)$. "Earned income" includes virtually all forms of wages, salary, and self-employment income, including nontaxable items. See infra note 146.

39 All tables and graphs make the simplifying assumption that total earnings ("earned income," defined in I.R.C. $\$ 32$ (c)(2) (Supp. V I993)) equals total income ("adjusted gross income," defined in I.R.C. $\$ 62$ (Supp. V. I993)). 


\section{TABle 2: 1996 EITC Benefits Under Current Law}

$\begin{array}{rr}\begin{array}{c}\text { Earnings } \\ \text { (= }\end{array} \\ \text { Income) } \\ \$ & 0 \\ \$ & 5000 \\ \$ & 8425 \\ \$ & 10,000 \\ \$ & 15,000 \\ \$ & 20,000 \\ \$ & 27,000\end{array}$

\section{EITC \\ Benefits}

$\$ 0$

$\$ 2000$

$\$ 3370$

$\$ 3370$

$\$ 2528$

$\$ 1475$

$\$ 0$
Total Income (including EITC)

$\begin{array}{lr}\$ & 0 \\ \$ 7,000 \\ \$ 11,795 \\ \$ 13,370 \\ \$ 17,528 \\ \$ 21,475 \\ \$ 27,000\end{array}$

These figures reflect EITC parameters for I 996 , expressed in I 994 dollars. See supra notes 33-39 and accompanying text. "Total Income" shows the sum of EITC and total (pre-tax, pre-transfer) earnings; it excludes other transfer benefits and federal and state taxes.

\section{GRAPH 1: THE EITC}

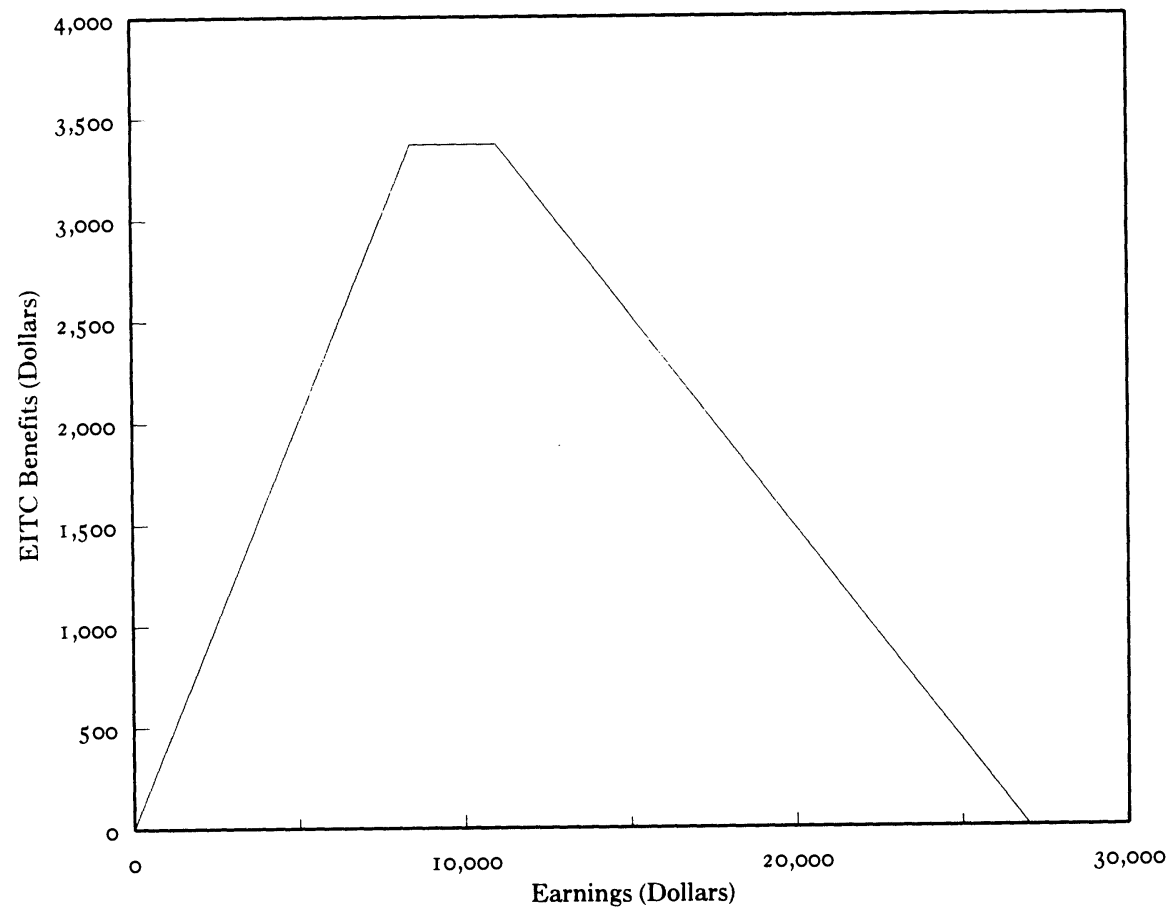

A worker may receive the EITC and other transfer payments as well. In general, the receipt of transfer payments by an EITC recipient does not affect the EITC benefit received. ${ }^{40}$ One way to

40 Income-tested transfer payments are not taken into account in determining adjusted gross income for purposes of the EITC, because they are generally excluded from income under administrative rulings of the I.R.S. See, e.g., Rev. Rul. 75-246, 1975-I C.B. 24 (ruling that non-compensatory allowances to employment-program trainees are excluded from income); Rev. Rul. 71-425, 
understand the interaction of the EITC with other taxes and transfers is to picture the EITC, other income-transfer programs, and the tax system as creating a single integrated system that provides transfers or collects taxes at each income level. At very low levels of income, people may be eligible for traditional income transfers and the EITC. At higher levels of income, the government simply imposes taxes. Graph 2 uses a hypothetical but realistic version of the U.S. tax-transfer system to show how the EITC alters the schedule of taxes and transfers. ${ }^{41}$

Graph 2: TAXES AND Transfers: $\$ 0-\$ 40,000$ INCOME

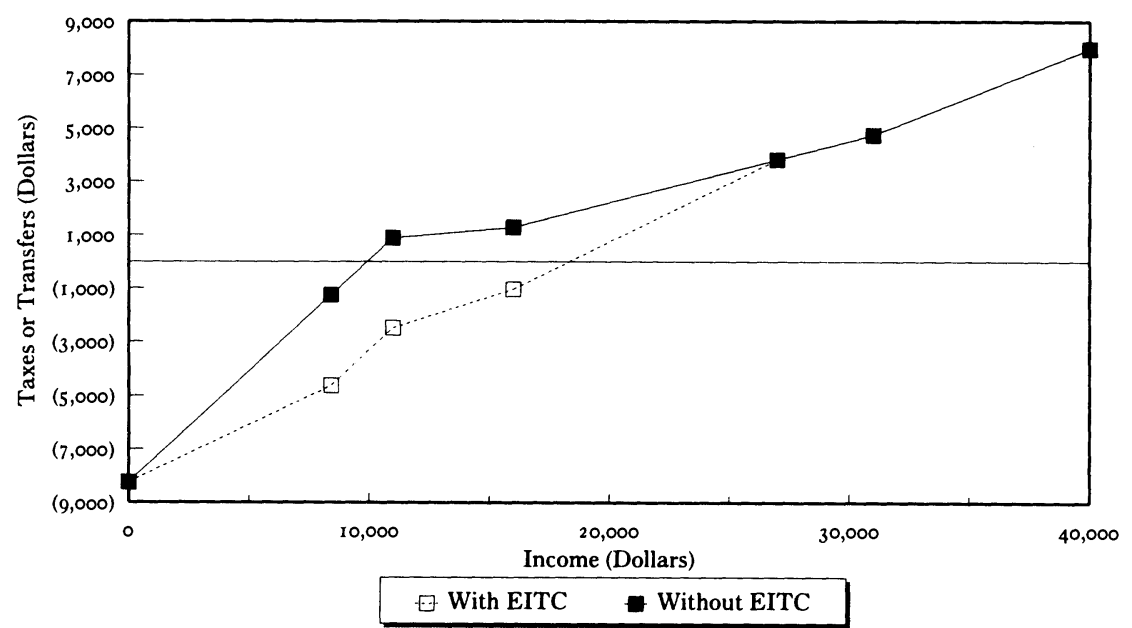

The EITC also differs from traditional transfers in administration. Traditional welfare programs use government workers to collect and

I97I-2 C.B.76 (ruling that state welfare payments to work program participants are excluded from income). A portion of Social Security benefits is included in income, but only for certain recipients. See infra note 153 . For purposes of AFDC, Food Stamps, and certain income-tested housing assistance programs, the EITC is not counted as income and is not counted as resources (assets) until the second month after the receipt of the EITC. See 42 U.S.C. $\$ \S 602(a)(7)(B)(i v)$, I382a(b)(I9), I382b(a)(ro) (Supp. V I 993); I.R.C. § 32(j) (Supp. V r 993).

41 Constructing a graph that reflects precisely the numerous federal and state transfer programs and taxes is beyond the scope of this Article. The hypothetical tax-transfer system includes the EITC, a single welfare program that roughly mimics the terms of AFDC and Food Stamps, a payroll tax, and an income tax with progressive marginal tax rates like those of the current federal income tax. The graphs and table are based on taxes and benefits for a parent and three children at different levels of income. The income support program provides a maximum benefit 
verify information about applicants and recipients. In contrast, the EITC is administered through the federal income tax system as a refundable tax credit. In theory, workers eligible for the EITC need never see a bureaucratic face..$^{42}$ They simply attach a special schedule to their federal income tax returns.

The IRS awards the EITC based on the information provided in the tax return. The EITC first offsets federal income tax liability (if any), and the balance is refunded in cash. The unusual ${ }^{43}$ refund feature makes it possible for the EITC to provide cash benefits to workers who are too poor to owe any tax or whose tax liability is less than their EITC benefit. ${ }^{44}$ The Code allows workers to claim projected EITC benefits from their employers throughout the year rather than as an annual lump sum, but virtually no EITC recipients choose this option. ${ }^{45}$

of $\$ 8250$, with a benefit reduction rate of $75 \%$. In contrast, in 1993 a family of four that received the median state's maximum AFDC benefit and the maximum Food Stamp benefit would receive a total annual benefit of $\$ 9720$. See 1994 GreEN Book, supra note 2, at 378, 769. AFDC imposes a nominal benefit reduction rate of $100 \%$, but the effective rate can vary significantly based on allowable expenses and other rules. See id. at 327-29. The Food Stamp Program imposes a benefit reduction rate of about $30 \%$, although the effective rate can vary. See id. at 768 . The hypothetical income tax system does not impose taxes on a worker with three children until her income exceeds $\$ 16,000$. Thereafter, the marginal income tax rates are $15 \%, 28 \%, 31 \%, 36 \%$, and $39.6 \%$, beginning at income levels of $\$ 16,001, \$ 31,001, \$ 79,001, \$ 128,001$, and $\$ 250,001$, respectively. Cf. Rev. Proc. 93-49, 1993-2 C.B. 581 (announcing 1994 inflation-adjusted rate brackets and a tax threshold of $\$ 15,400$, composed of a standard deduction of $\$ 5600$ and four personal exemptions of $\$ 2450$ each). The hypothetical system omits the phase-out of personal exemptions at high income levels required by I.R.C. $\S$ I I I(d)(3) (Supp. V I993). The hypothetical payroll tax is eight percent capped at wages of $\$ 60,000$. See OASDI Contribution and Benefit Base and the Repeal of the Hospital Insurance Contribution Base, 1993-36 I.R.B. 39; cf. I.R.C. § 3 Ior(a), (b) (I988) (mandating a payroll tax of $7.65 \%$, which includes a $6.2 \%$ Social Security tax and a base for this portion of the tax capped at $\$ 60,600)$. In addition, the graph assumes that the family's sole source of income is its earnings, which are subject to both income and payroll taxes.

42 But see infra note 123 (noting that a significant portion of EITC recipients participating in a recent survey rely on paid tax preparers); infra p. 590 (questioning whether tax preparers are in effect serving as case workers).

43 The only refundable tax credits in the Code are the EITC and credits for payments of federal income or excise taxes. See I.R.C. $\$ \$ 3$ I-35 (I988 \& Supp. V 1993).

44 For example, a single worker who earns $\$ 20,000$ and has three children will be entitled to an EITC of about $\$ 1475$ beginning in 1996. See id. $\$ 32$ (1988 \& Supp. V 1993). At I994 federal income tax rates, standard deduction levels, and personal exemption levels, see id. $\$ \S \mathrm{r}(\mathrm{b}), 63$ (c), I5 I (I 988); Rev. Proc. 93-49, supra note $4 \mathrm{I}$, her federal income tax liability is about $\$ 690$. The EITC would reduce her federal tax liability to zero, and she would receive a cash "refund" of $\$ 785$.

45 See infra p. 581. 


\section{How the EITC Debate Overstates the Importance of BEHAVIORAL DisinCENTIVES}

Conventional policy debates over the EITC, like debates over welfare policy, ${ }^{46}$ are dominated by economic analyses that focus on potential disincentives for work and marriage. This Part argues that these narrowly focused debates are analytically incomplete and reflect considerable normative confusion. Although advocates of the EITC have probably exaggerated its positive effects on labor supply, critics of the EITC give undue weight to potential negative effects on work effort. They rely on an "economic" analysis that departs significantly from both the analytic conventions and the standard normative underpinnings of traditional economic theory. The standard criticism of the EITC's potential disincentives for marriage proceeds without acknowledging the need for empirical support and overlooks the inevitable trade offs among competing policy goals that constrain design of the EITC, as well as of traditional transfer programs. These dominant debates over the EITC's behavioral effects have distorted comparisons of alternative programs and have enshrined an apparently neutral mode of analysis that is in fact biased against redistribution.

In the following discussion, it is essential to distinguish disincentives from the effects of those disincentives on behavior. Economic theory can establish the existence of disincentives to work or to marry, but empirical study is needed to establish whether and how those disincentives actually affect people's decisions to work or to marry. For example, whether work disincentives actually reduce work effort depends on the strength of people's preferences for work and the extra income work generates compared to leisure or other activities. Those preferences may be shaped by a variety of forces, including the availability of incrementally longer or shorter work hours, and family responsibilities. There is a wealth of empirical evidence on traditional welfare programs' impact on work, ${ }^{47}$ but that evidence is both difficult to interpret and uneven in its coverage of different types of workers. ${ }^{48}$ To be as clear as possible for all readers, and at the cost of deviating from standard economic terminology, I will refer to "potential" disincentives to emphasize the tentative nature of theoretical predictions.

The argument in this Part is critical rather than prescriptive. My goal is to reveal the analytical oversights and normative inconsistencies in current policy analyses of the EITC, while remaining within

46 See Piven \& Cloward, supra note 17 , at $72-73$.

47 See infra note $5^{2}$ (citing several empirical studies on welfare's impact on work).

48. See generally Anthony B. Atkinson \& Joseph E. Stiglitz, Lectures on Public EcoNOMICS $57 \mathrm{I}$ ( $\mathrm{I} 980$ ) (noting that the question of the impact of income maintenance programs on labor supply and savings is a "complicated question, and individuals may be affected very differently"). "This variation makes it difficult to interpret the empirical evidence - even in this relatively well researched area." Id. 
the framework of traditional economic analysis that both sides in the debate purport to use. A normative evaluation of the appropriate role of economic analysis in policy evaluation and the proper weight to be given to the behavioral effects of the EITC and other redistributive programs is beyond the scope of this Article, although that task forms an important part of my long-term project. ${ }^{49}$

\section{A. A Critical Evaluation of the Significance of Potential and Actual Work Disincentives in the EITC}

One classic dilemma of redistribution is the potential trade off between redistribution and labor supply. Redistributive programs may decrease total economic output if they reduce work effort by incometransfer recipients or by taxpayers who finance the program..$^{50}$ Thus, reductions in work effort raise the economic cost of redistributive programs. Even those analysts most committed to distributive justice for the least advantaged have grappled with this economic constraint. ${ }^{51}$ Empirical studies suggest that redistributive programs on balance probably have a small but nontrivial negative effect on work effort and that specific transfer programs can vary in their effects, but analysts differ on the magnitude of the actual work disincentives found. ${ }^{52}$

49 Current discussions of welfare and work, for example, often fail to recognize the social value of nonmarket work such as child care and instead characterize single mothers who receive welfare and do not hold jobs as "deviant." See generally MARTha A. Fineman, The Neutered MOTHER (forthcoming 1995) (arguing that single mothers are viewed as "deviant" in poverty discourses and that welfare policy rests on the normative claim that families should be supported by male breadwinners); Carole Pateman, The Patriarchal Welfare State, in Democracy AND THE Welfare STATE 23I, 23I-60 (Amy Gutmann ed., 1988) (arguing that American welfare policy fails to recognize women's nonmarket work and denies women full citizenship by considering only market work in determining the type of assistance people receive). A critical evaluation of discourses about welfare and work might also question the social function of the work ethic and punitive treatment of nonworkers. See generally HANDLER \& HASENFELD, supra note II, at I I-I 3 (arguing that welfare systems separate poor workers from poor nonworkers to reinforce the work ethic); Piven \& Cloward, supra note I 7, at 92-IOI (arguing that the availability of welfare increases the financial security of the poor by lessening the importance of the unpredictable labor market).

50 Redistributive programs may also reduce savings. See R. Glenn Hubbard, Jonathan Skinner \& Stephen P. Zeldes, Why Do People Save? Expanding the Life-Cycle Model: Precautionary Saving and Public Policy, AM. ECON. REV., May 1994, at 174, 175 (arguing that the asset-based means testing of AFDC, Social Security Insurance (SSI), and Medicaid may significantly depress savings by low-income households).

51 In an extreme case, redistributive programs might, through their effects on economic output, make even the least advantaged worse off. See JoHN RAWLS, A THEORY OF Justice 285-86 (1971). See generally Amartya Sen, INEQuality Reexamined 137 (1992) (describing the conflict between aggregative and distributional considerations).

52 The general literature on the labor-supply response to income-maintenance programs is too voluminous to cite completely. See, e.g., Sheldon Danziger, Robert Haveman \& Robert Plotnick, How Income-Transfer Programs Affect Work, Savings, and the Income Distribution: A Critical Review, I9 J. ECON. LIT. 975, 1020 (I98I) (estimating that income-transfer programs reduce total labor supply by about $4.8 \%$ but adding that "the research findings are too varied, too uncertain, 
Contrary to EITC advocates' claims, microeconomic theory shows that the EITC does not necessarily increase work effort among the poor, and may actually reduce it. This Part begins by presenting the standard, static analysis of labor supply that is commonly used to analyze the labor-supply effects of the EITC and other redistributive programs. ${ }^{53}$ Though simplified, ${ }^{54}$ this model of labor supply suffices to show the inherent ambiguities in claims about the EITC's effects on

and themselves too colored with judgment to serve as more than a rough guide to policy choices"); Robert Moffitt, Incentive Effects of the U.S. Welfare System: A Review, 30 J. EcoN. LIT. I, I6 (I992) (arguing that AFDC generates "nontrivial" reductions in work but noting that, "as is frequently the case, the estimates of effects vary considerably across the available studies for reasons usually difficult to explain"); Philip K. Robins, A Comparison of the Labor Supply Findings From the Four Negative Income Tax Experiments, 20 J. Human Resources 567, 573 (1985) (observing that experiments found "an unambiguous decrease in labor supply" but that "in no case is there evidence of a massive withdrawal from the labor force" and reporting that decreases in hours worked ranged from five to twenty-five percent). Data also typically show that few recipients of AFDC work. See, e.g., 1994 GREEN Book, supra note 2, at 404 (showing that, in 1992, only $6.4 \%$ of female adult AFDC recipients worked part-time or full-time). But see Kathleen $\mathbf{M}$. Harris, Work and Welfare Among Single Mothers in Poverty, 99 Ам. J. Soc. 31 7, 31 7, 344-46 (I993) (finding that the majority of women on welfare work at some point during a spell on welfare); Kathryn Edin \& Christopher Jencks, Reforming Welfare, in RETHINking Social Policy 204, 2 14-18 (Christopher Jencks ed., 1992) (finding, in a study of 50 welfare mothers, that virtually all of them work but fail to report their earnings).

53 See 1993 Welfare Reform Hearings, supra note 29, at 90-93 (testimony of Gary Burtless); U.S. General Accounting Office, Earned Income Tax Credit: Design and AdministraTION Could Be Improved 45-52 (GAO/GGD-93-145, Sept. 1993); Saul D. Hoffman \& LaURence S. Seidman, The Earned Income TAX Credit: Antipoverty Effectiveness and LABOR Market Effects 39-50 (1990); Robert L. Moore, Recent Proposals to Redesign the EITC: An Economist's Response, 59 TAX Notes 105, 105-07 (1993).

54 First, the standard analysis implicitly assumes that workers can choose whether to work a marginal hour. This assumption may be true in some cases, such as for a worker who can accept or reject hours of overtime, but is probably untrue in cases in which labor-supply choices are "lumpy." For example, a nonworker may be choosing between having no job and having a $20-$ or 40-hour a week commitment, and someone already in the labor force may be able to choose only whether to take on a second job. In the long run, the opportunities for adjustment are probably greater than in the short run. The choices, however, may remain somewhat lumpy given the structure of the labor market. See U.S. General ACCOUNTING OFfICE, supra note 53, at 45-47.

Second, decisions about work may be made jointly with other family members, or work may be undertaken for reasons other than the wage alone - for example, work may entitle workers to social insurance benefits or to higher levels of such benefits. For a richer discussion of these and other determinants of labor supply, see AtKinson \& STIGLiTZ, cited above in note 48, at 43-48; and Danziger, Haveman \& Plotnick, cited above in note 52, at 979-80. Third, reductions in labor supply may have dynamic consequences not captured here. For example, income transfers may make workers more selective in choosing jobs. Although that selectivity may reduce labor supply in the short run, in the long run it could increase productivity if workers find better or more stable jobs. Finally, the analysis abstracts from macroeconomic conditions, including the level of unemployment, which affect the ability of willing workers to find jobs.

The following discussion, like most current analyses of the EITC, assumes that the economic benefits of the EITC accrue to the recipient, and not to her employer. However, the incidence of the EITC, like that of other subsidies, is not entirely certain. Depending on how markets adjust, employers or even customers, rather than workers, could capture the economic benefit of the EITC in whole or in part, if employers can identify EITC-eligible workers and reduce their wages accordingly. See Shapiro \& GREenstein, supra note 8, at 28-29. 
work and to provide background for understanding EITC advocates' and opponents' normative economic arguments.

The standard analysis assumes that workers and potential workers understand how the EITC, the tax system, and the welfare system affect their earnings. Because the EITC is complex, however, EITC recipients may not understand the connection between work and the EITC benefits they receive. This informational gap may blunt both the EITC's potential incentives and its potential disincentives. ${ }^{55}$

Standard economic analysis suggests that the EITC creates competing potential work incentives and disincentives that vary among groups of workers. As Part II describes, the EITC combines three distinct elements: an earnings subsidy, a "stationary" range, and a "phaseout" or income test. For workers with earnings in the earnings subsidy range, the EITC acts as a proportional pay increase, which provides up to four dollars for every ten dollars of earnings. A casual observer might suppose that a pay raise necessarily increases work effort, but economic theory suggests that the earnings subsidy may either increase or decrease work by a worker who is already employed. The earnings subsidy increases the return to work relative to other activities (for example, leisure), and this "substitution effect" may increase people's proclivity to work rather than to consume leisure. On the other hand, EITC benefits provide extra money, which allows the worker to consume as much as before with less work. This "income effect" may lead the worker to consume more leisure, depending on her preferences. The net impact on work depends on the relative magnitudes of these competing effects. ${ }^{56}$ Importantly, however, the EITC's potential incentives are different for a nonworker contemplating entering the workforce. For her, the EITC is an unambiguous potential work incentive; she receives no income support from the EITC unless she goes to work and so the income effect is absent. ${ }^{57}$

In contrast, workers with incomes in the stationary range, who receive an EITC benefit that does not vary with earnings, face a poten-

55 Although more research is needed, anecdotal evidence suggests that there may be significant confusion about the terms of the EITC. For example, the fact that the EITC is received as a tax refund rather than throughout the year in the paycheck may blur the link between the EITC and work. See Lynn M. Olson with Audrey Davis, The Earned Income Tax Credit: Views From the Street Level I2-I3 (Northwestern Univ. Ctr. for Urban Affairs and Policy Research Working Paper No. 94-I, I994).

56 A similar predictive ambiguity occurs in the analysis of an income tax, which lowers the return to work and creates competing income and substitution effects. Once again, theory cannot predict even the direction (let alone the magnitude) of the net effect on work effort. Empirical studies vary in their estimate of the responsiveness of labor supply to income tax changes. See Harvey S. Rosen, Public Finance 4I3-24 (3d ed. i992).

57 See Moore, supra note 53, at 106 \& n.9; C. Eugene Steuerle, Tax Credits for Low-Income Workers with Children, J. ECON. PERSP., Summer 1990, at 201, 209. If a nonworker receives other forms of income support, the benefit reduction rates in the other programs may offset the EITC's potential incentive effects. 
tial work disincentive. The earnings subsidy is no longer available with respect to extra earnings, so the EITC substitution effect neither encourages nor discourages work relative to leisure. Further, the income effect (or the feeling of being better off with less work) may discourage work. ${ }^{58}$

For workers with earnings in the EITC phase-out range, additional earnings reduce EITC benefits, just as in a traditional income-transfer program. This incremental benefit reduction as income rises is analogous to a tax on income: although the tax does not add to the government's coffers, the worker keeps less than a dollar for each additional dollar earned. This benefit reduction, like any actual tax, reduces the net monetary reward for extra work. EITC recipients who also pay income and payroll taxes or who participate in other income-transfer programs can find that multiple marginal tax rates apply to the same dollars of earnings, and cumulative potential work disincentives can be quite large. For example, the EITC's benefit reduction rate is twenty-one percent, but EITC recipients who also pay federal income and payroll taxes face a cumulative marginal tax rate as high as fortyfour percent, without taking into account state taxes or benefit reductions in other income-transfer programs. ${ }^{59}$

Graph 3 shows the EITC's effects on marginal tax rates at different levels of income in the hypothetical but realistic tax-transfer system depicted in Graph 2 in Part II. At very low levels of income, the EITC's earnings subsidy creates a negative marginal tax rate that offsets, at least in part, the marginal tax rates that other taxes or transfers create. At slightly higher income levels, however, the EITC increases marginal tax rates. Table 3 summarizes the total taxes, transfers, and marginal tax rates that correspond to different levels of income in this hypothetical system.

For workers in the EITC phase-out range, the EITC creates an unambiguous potential work disincentive. In this income range, the EITC's substitution effect may discourage work effort because the phase-out of EITC benefits, like a tax, reduces the net wage. Further, an EITC recipient in the phase-out range has a higher total income than a worker with no EITC benefit, and thus the EITC's income effect also may discourage work effort. ${ }^{60}$

58 See Hoffman \& SEIDMan, supra note 53 , at $4 \mathrm{I}$.

59 The $44 \%$ figure is comprised of a $21 \%$ EITC phase-out, a $15 \%$ federal income tax, and a $7.62 \%$ Social Security payroll tax. These simple figures, however, are quite rough; estimating actual marginal tax rates for participants in multiple programs is extremely difficult. For a simulation of explicit and implicit tax rates, see Stacy Dickert, Scott Houser \& John K. Scholz, Taxes and the Poor: A Microsimulation Study of Implicit and Explicit Taxes, 47 NAT'L TAX J. 62I, 624-36 (1994).

60 See Hoffman \& Seidman, supra note 53 , at $4 \mathrm{I}$. 
Graph 3: Marginal Tax Rates and the EITC

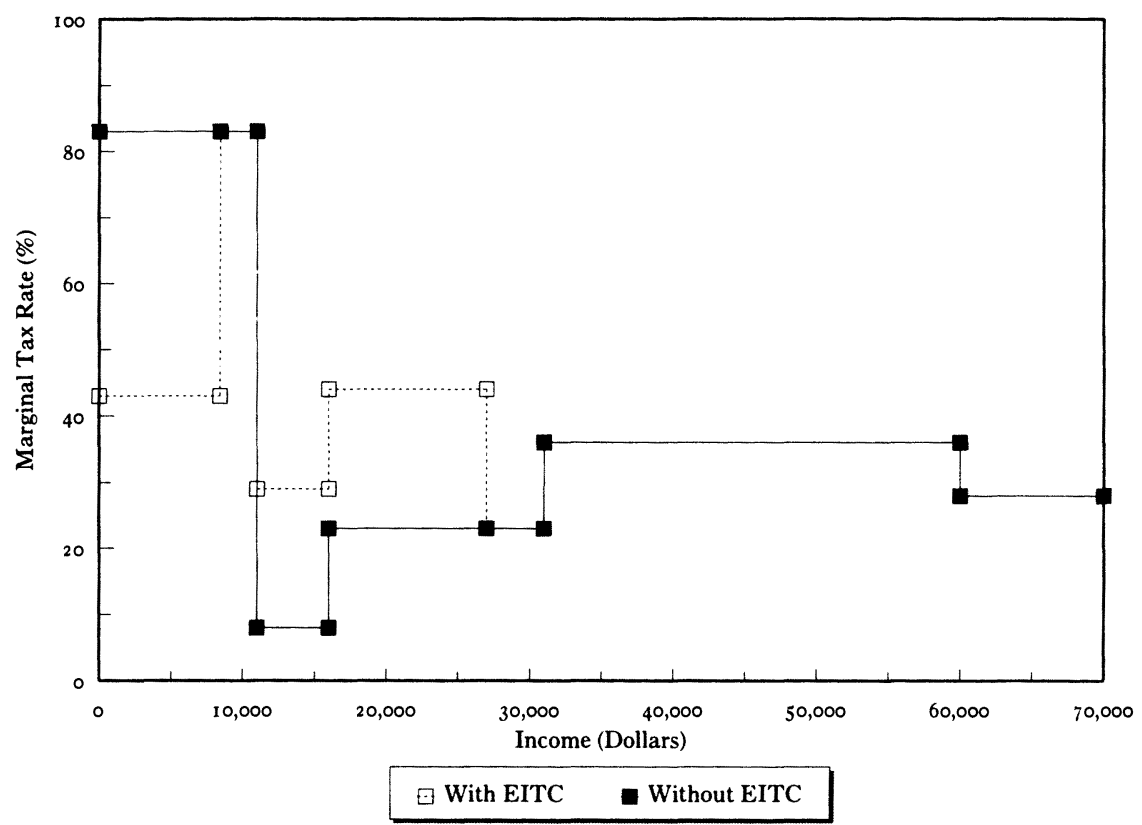

Table 3: Marginal Tax Rates in a Hypothetical

(But Realistic) Tax and Transfer System

Income and

$\begin{array}{lccccc}\text { Income } & \begin{array}{c}\text { Payroll } \\ \text { Taxes }\end{array} & \begin{array}{c}\text { Transfers } \\ \text { (including EITC) }\end{array} & \begin{array}{c}\text { Marginal } \\ \text { Tax Rate }\end{array} & \begin{array}{c}\text { Total Taxes (+) or } \\ \text { Transfers (-) }\end{array} \\ \$ 1000 & \$ & 80 & \$ 7900 & 43 \% & -\$ 7820 \\ \$ 8000 & \$ & 640 & \$ 5450 & 43 \% & -\$ 4810 \\ \$ 10,000 & \$ 800 & \$ 4120 & 83 \% & -\$ 3320 \\ \$ 15,000 & \$ 1200 & \$ 2528 & 29 \% & -\$ 1328 \\ \$ 20,000 & \$ 2200 & \$ 1475 & 44 \% & +\$ 725 \\ \$ 30,000 & \$ 4500 & \$ & 0 & 23 \% & +\$ 4500 \\ \$ 40,000 & \$ 7970 & \$ & 0 & 36 \% & +\$ 7970 \\ \text { \$61,000 } & \$ 15,450 & \$ & 0 & 28 \% & +\$ 15,450\end{array}$

Although microeconomic theory can make limited predictions about the EITC's potential effects on different groups of workers, only empirical evidence can determine whether the EITC on balance encourages or discourages work. In theory, the EITC might do either. Early estimates of the EITC's impact on work effort suggest that the 
EITC reduces work effort in the aggregate, but probably by a smaller amount than do traditional welfare programs. ${ }^{61}$ These studies are open to criticism on methodological grounds, however. ${ }^{62}$ In addition, the I993 changes in the EITC program may have altered the EITC's labor-supply effects by increasing the earnings subsidy and changing the proportion of EITC recipients in the phase-in, stationary, and phase-out ranges. ${ }^{63}$

Although potential work disincentives are inherent in the EITC and other income-tested transfer programs, it might appear that such disincentives could be reduced by lowering benefit reduction rates. The success of such changes in EITC design may be limited, however, by two dilemmas that also constrain welfare program design. First, reducing marginal tax rates creates difficult and politically troublesome trade offs. In an income-tested transfer program such as the EITC, it is impossible simultaneously to provide generous benefits, to keep program costs low by paying benefits only to the poor, and to keep benefit reduction rates low. ${ }^{64}$ Reducing the marginal tax rate means that benefits decline at a slower rate as income rises and thus

61 See id. at $43-47$. The authors estimate that, in 1988 , the EITC reduced the labor supply of EITC recipients as a group by about two percent. Although workers in the earnings subsidy range increased their work effort by about two percent, the increase was more than offset by the reduced labor supply of higher-earning groups. See id.; see also 1993 Welfare Reform Hearings, supra note 29, at 9I (testimony of Gary Burtless) (arguing that the EITC has a "very small" work disincentive effect in comparison to other transfer programs); U.S. General Accounting OFFICE, supra note 53, at 50-52 (estimating that, in 1988 , the EITC reduced the aggregate labor supply of EITC recipients by two percent and projecting that in I994, under pre-I993 law, the EITC would reduce the aggregate labor supply of EITC recipients by $3.6 \%$ ). For an excellent survey of studies of the effects of transfer programs on labor supply and the implications of the findings for analysis of the EITC, see Stacy Dickert, Scott Houser \& John K. Scholz, The Earned Income Tax Credit and Transfer Programs: A Study of Labor Market and Program Participation, in Tax Policy and the Economy I, 3-17 (James M. Poterba ed., 1994), reprinted in 94 Tax Notes TODAY 222-62 (Nov. 22, 1994).

62 See, e.g., John K. Scholz, The Earned Income Tax Credit: Participation, Compliance, and Antipoverty Effectiveness, 47 NAT'L TAX J. 63, 78-79 (1994); Steuerle, supra note 57, at 209. In addition, these studies measure only increases or decreases in hours of work by EITC recipients already in the labor force and do not measure the EITC's effect on labor force participation. A recent study estimates that the I993 EITC changes will have a significant positive effect on labor force participation by single parents. See Dickert, Houser \& Scholz, supra note 6I, at 3, 34-35.

63 According to John Karl Scholz, the 1993 changes increased by $42 \%$ the number of EITC recipients who are eligible for the earnings subsidy, primarily by extending the EITC to childless workers. At the same time, however, the 1993 changes "almost double" payments to workers in the phase-out range. See Scholz, supra note 62, at 78 . Three Treasury economists estimate that the 1993 changes in the EITC will cause earnings among EITC recipients with children to fall by 2.4\%. See Janet Holtzblatt, Janet McCubbin \& Robert Gillette, Promoting Work Through the EITC, 47 NAT'L TAX J. 59I, 599 (1994).

64 The interaction among those variables in the EITC is complicated by the addition of three new variables: the earnings subsidy rate, the income level at which phase-in ends, and the income level at which phase-out begins. See Hoffman \& Seidman, supra note 53, at 64-66. For discussions of these trade offs in traditional income-transfer programs, see IRWIN GARFINKEL \& SARA Mclanahan, Single Mothers and Their Children i 79-80 (I986); Green, supra note 6, at 
become available to a larger and relatively richer group. ${ }^{65}$ The only way to reduce marginal tax rates without expanding the pool of eligible recipients is to reduce benefits.

The recent expansion of the EITC illustrates the intractability of these trade offs. Legislation expanding the EITC in 1990 increased the benefit reduction rate from ten to eighteen percent. ${ }^{66}$ The Clinton administration proposed another substantial increase in EITC benefits in February 1993 but expressed concern about the potential disincentive effects of increasing the EITC marginal tax rate still further. ${ }^{67}$ The administration's original proposal would actually have lowered marginal tax rates in the EITC but at the cost of increasing the income cutoff dramatically - to $\$ 30,000$ for families with two or more children. ${ }^{68}$ Apparently in response to charges that the plan awarded too great a fraction of benefits to relatively well-off recipients, the administration changed its proposal to incorporate a somewhat higher marginal tax rate than the original plan and a lower income cutoff. ${ }^{69}$ The final legislation provides a benefit reduction rate of twenty-one percent and an income cutoff of $\$ 27,000 .{ }^{70}$

68-8i; James C. Ohls \& Harold Beebout, The Food Stamp Program: Design Tradeoffs, POLICY, AND IMPACTS 40-43 (I993).

65 The increased revenue cost of the larger program may also require raising taxes. The distortionary effects of those taxes add further to the cost of the program change and may even outweigh its benefits.

66 See Pub. L. No. I0I-508, § iri I I, I04 Stat. I388, I388-408 to -09 (I990), amended by Omnibus Budget Reconciliation Act of 1993, Pub. L. No. 103-66, § I3131, I07 Stat. 312, 433-35 (I 993) (codified at I.R.C. $\$ 32$ (I988 \& Supp. V I 993)). The I990 legislation increased the EITC's maximum benefit (by raising the earnings subsidy percentage) but continued to cut off benefits at $\$ 20,264$ of income. See H.R. Rep. No. 964, rorst Cong., 2d Sess. I035-36 (1990), reprinted in I990 U.S.C.C.A.N. $2374,2740-4$ I (noting that, under prior law, the EITC credit rate was $14 \%$ of the first $\$ 6,810$ of earnings and that the EITC phase-out rate was 10\% for earnings over $\$ 10,730)$. Under these parameters, the EITC was completely phased out at earnings of $\$ 20,264$ [( $(.14 \mathrm{x}$ $\$ 68$ Io $)$. I0 $(\$ 20,264-\$ 10,730))=\$ 953.40-\$ 953.40=0$ o]. The 1990 Act raised the credit rate to $25 \%$ of the first $\$ 6810$ of earnings and increased the phase-out rate to $17.86 \%$. Id. at 1036 . These new parameters also imply an EITC income cutoff of $\$ 20,264[((.25 \times \$ 6810)-.1786$ $(\$ 20,264-\$ 10,730))=0$ ]. As a consequence, the benefit reduction rate rose from 10\% to nearly $18 \%$.

67 See U.S. Dep't of the Treasury, Summaries of the Administration's Revenue Proposals, Feb. I9, I993 (draft), reproduced in 93 TAX Notes TODAY 43-I, 79, 121, Feb. 23, 1993, available in LEXIS, Fedtax Library, Taxtxt File.

68 See id. at $\mathrm{I} 2 \mathrm{I}-22$ (describing an earnings subsidy of $40 \%$, a phase-out rate of $13.76 \%$, and an income cutoff of $\$ 30,000)$.

69 See Timothy Noah \& Laurie McGinley, Advocate for the Poor, Respected on All Sides, Secures a Pivotal Role in Expanding Tax Credit, Wall St. J., July 26, I993, at $\mathrm{A}_{12}$ (explaining that objections by Robert Greenstein led the Clinton administration to revise its I993 EITC proposals); see also 1993 Welfare Reform Hearings, supra note 29, at I8-19 (testimony of Samuel Y. Sessions, Deputy Assistant Secretary (Tax Policy), Dep't of the Treasury) (describing the administration's revised proposal as of March 30, 1993, which contained a $39.7 \%$ credit, a $19.83 \%$ phaseout rate, and a $\$ 28,000$ income cutoff).

70 See I.R.C. $\$ 32$ (b) (Supp. V I 993). The 1993 legislation also reduced the income level at which benefit reduction first occurs to $\$ 11,000$. See $i d$. 
The second dilemma is that lowering benefit reduction rates may not increase aggregate labor supply. ${ }^{71}$ Although lowering the EITC's marginal tax rate reduces potential work disincentives for current program participants in the phase-out range, it raises the income cutoff (if benefit levels and other parameters are constant). As a consequence, a new set of recipients becomes eligible for benefits - and subject to the attendant work disincentives. Thus, a decrease in marginal tax rates increases aggregate labor supply among program participants only if the increase in work effort by current recipients outweighs the decrease in work effort by new recipients. Studies of past changes in AFDC benefit reduction rates suggest that the two effects may cancel each other out, ${ }^{72}$ but no corresponding studies of the EITC have been undertaken.

As the EITC has outgrown its traditional role as tax relief for the poor to become an expensive, large-scale income-transfer program, opponents have used the theoretical and empirical charge of work disincentives to attack the EITC. For example, one prominent critic of the EITC, economist Marvin Kosters, argues that the 1993 expansion of the credit was misguided. ${ }^{73}$ Kosters contends that the effects on total economic output of the EITC's potential work disincentives are likely to be large, because many more EITC recipients fall in the EITC's phase-out range than in the earnings subsidy range, and workers in the phase-out range are more productive. ${ }^{74}$ Kosters argues, in effect, that it makes little sense to provide a potential work incentive for a relatively small number of welfare recipients at the cost of creating potentially large reductions in the work effort of many more poor workers who are already working. ${ }^{75}$

The EITC's advocates respond with two arguments. First, some commentators claim that the EITC is a desirable policy, because its

71 See Gary Burtless, The Effect of Reform on Employment, Earnings, and Income, in WELFARE POLICY FOR THE 1990s, supra note 18, at 103, 133; Robert Moffitt, A Problem with the Negative Income Tax, I7 ECON. LeTters 26I, 26I-65 (I985). Hoffman and Seidman note the possible operation of this effect in the EITC. See HofFMAN \& SEIDMAN, supra note 53, at 43-47.

72 See Burtless, supra note 7I, at I30-34; Moffitt, supra note 52, at 4I.

73 See Marvin H. Kosters, The Earned Income Tax Credit and the Working Poor, AM. ENTERPRISE, May/June I993, at 64, 68-70.

74 Kosters estimates that, before the 1993 legislation, the ratio of EITC recipients in the stationary and income test ranges of the EITC to those in the earnings subsidy range was about five or six to one. He projects that, under the Clinton administration's Spring 1993 proposal to expand the EITC and raise the income cutoff to $\$ 28,000$, the ratio would have risen to about eight or nine to one. See id. at 68-69; see also 1993 Welfare Reform Hearings, supra note 29, at II I-I4 (testimony of Marvin Kosters) (arguing that the Clinton proposal increases the percentage and the absolute number of EITC recipients who face potential work disincentives). The I993 amendments ultimately raised the income cutoff to $\$ 27,000$. See supra note 38 .

75 See Kosters, supra note 73 , at 72 . Kosters mentions that distributional considerations as well as work disincentives should be considered in evaluating the EITC but does so in one line of an article devoted entirely to the EITC's potential work disincentives. See id. 
aggregate work disincentives are likely to be smaller than those of traditional welfare programs. ${ }^{76}$ Although this claim seems plausible, more empirical work is necessary to substantiate any conclusions about the current EITC's aggregate effects. ${ }^{77}$ Second, other proponents say, the EITC's aggregate effects on labor supply, whatever they may be, do not tell the whole story: the effects of the EITC on work by different groups of EITC recipients are also important for social policy. Estimates of the EITC's labor-supply effects suggest that it increases work effort by a small amount, on net, for the very poor workers in the earnings subsidy range. ${ }^{78}$ EITC advocates argue that this effect is crucial, because the credit provides the greatest potential work incentives to the poorest recipients and to nonworkers, who begin with the weakest attachment to the labor force. At the same time, the EITC's income test concentrates potential disincentives on slightly higher-income workers who already are in the work force instead of on all program participants. ${ }^{79}$ These features may improve labor-force participation over time by easing the transition from welfare to work. ${ }^{80}$ Thus, EITC proponents characterize it as an "anti-underclass" program - a way of moving the poorest and most disadvantaged potential workers into the labor force. ${ }^{81}$ These arguments concede that potential and actual work disincentives are properly viewed as undesirable features of the EITC but argue that incentives for some groups are more important than disincentives for others. ${ }^{82}$

The central problem with the conventional debate is that it focuses too narrowly on work disincentives. First, the "work disincentive" label carries a pejorative weight in the writings of both advocates and opponents of the EITC that is unjustified in conventional economic analysis. Even if the EITC leads some recipients to work fewer hours, these workers would be making a rational choice to use the extra dollars added to their wages by the EITC to buy a few hours of leisure

76 See 1993 Welfare Reform Hearings, supra note 29, at 92 (testimony of Gary Burtless); George K. Yin, Summary of EITC Conference Proceedings, II AM. J. TAX PoL'y 299, 3 IO-I I (1994).

77 See supra pp. 549-5 I (describing the limitations of existing estimates of the EITC's laborsupply effects).

78 See supra note 6r.

79 See Hoffman \& Seidman, supra note 53, at 47; Shapiro \& GREenstein, supra note 8, at 30.

80 A recent study concluded that the EITC may increase labor-force participation, particularly by single parents. See Dickert, Houser \& Scholz, supra note 6I, at 3, 34-35.

81 See, e.g., Mickey Kaus, Credit Where Due, New Republic, Aug. 2, 1993, at 6.

82 See, e.g., 1993 Welfare Reform Hearings, supra note 29, at 92 (testimony of Gary Burtless) (noting that the EITC's work disincentives are smaller than those of other transfers). In addition, most descriptive analyses of the EITC focus on potential and actual work disincentives and thus reflect prevalent concerns. See, e.g., Holtzblatt, McCubbin \& Gillette, supra note 63, at 596-99; Scholz, supra note 62 , at $76-79$. 
or time for nonmarket work (for example, child care). ${ }^{83}$ Although the EITC recipients' pre-transfer wages would decline due to the reduction in work effort, their total economic incomes would rise. The new package of cash earnings, cash transfer, and leisure would make them, on net, better off. Further, if EITC recipients use their additional time for nonmarket work, such as care for children, the elderly, and the sick, their choice benefits these other people and, potentially, society as a whole. ${ }^{84}$ Thus, the potential labor-supply reductions that some policy analysts find so troubling actually would increase the well-being of the poor. ${ }^{85}$ In economists' terms, these free and rational choices between work and leisure maximize utility, which is the central norm that animates traditional economic analysis.

Merely recognizing the potential economic value of reductions in market work does not, of course, provide any definite means of weighing the economic costs and benefits of the EITC. Nevertheless, insisting on that recognition adds an important dimension to the policy debate. Although careful economists recognize this point, it is too often disregarded in policy analyses as a technical detail rather than a crucial aspect of the economics of income transfers. ${ }^{86}$

The relationship between utility and leisure affects analyses of traditional welfare programs as well, of course. A welfare recipient who chooses to "buy" leisure is also making a utility-maximizing choice. For institutional reasons, however, the stakes differ in the EITC and welfare, because welfare programs may allow recipients not

83 Marvin Kosters notes the "theoretical" relevance of leisure to the analysis of work disincentives, but only in arguing against the EITC. Kosters argues that, if the EITC induces nonworkers to work, "there is at least the theoretical cost to them of the loss of leisure." Yin, supra note 76 , at $3 \mathrm{II}$. But this point is incomplete: although nonworkers have less leisure than they had before the EITC, their decision to work in exchange for an EITC benefit implies that they value the package of EITC plus work more than the package of no EITC plus more leisure. In other words, the EITC makes recipients better off, on net, whether they work more or less.

84 Feminists have emphasized the social value of nonmarket work, including caregiving, that is typically though not exclusively performed by women. See, e.g., NANCy Folbre, Who Pays FOR THE KIDS? 95-98 (I994) (describing the social importance of family labor and the exclusion of family labor from conventional measures of economic activity).

85 Cf. Stanley Masters \& Irwin Garfinkel, Estimating the Labor Supply Effects of Income Maintenance Alternatives 2 (1977) (arguing that reductions in gross national product due to reductions in the labor supply of income maintenance recipients "is largely offset by the value of the corresponding increases in leisure"); Edgar K. Browning \& William R. Johnson, The Trade-Off Between Equality and Efficiency, 92 J. PoL. ECON. 175, I97-201 (1984) (observing that adjusting estimates of the net efficiency cost of redistribution to take into account the value of leisure increases the measured benefits of redistribution to transfer recipients and lowers the measured detriment to high-income taxpayers who reduce work effort in response to taxes).

86 Economists may prefer to quantify the costs of labor-supply reductions rather than to specify and to defend normative views about the social benefits of redistribution. The danger, however, is that the legitimately narrow focus of economic scholarship can distort the terms of the broader policy debate. 
to work at all. ${ }^{87}$ Reframed, the question of work and welfare becomes this: should welfare recipients be required to work even if it reduces their current utility?88 Many argue that they should, to improve their long-term prospects, to avoid "dependency" on the state, or to meet a fundamental duty of citizenship, for example. ${ }^{89}$

The EITC is a different story. EITC recipients, unlike welfare recipients, cannot stop working altogether if they want to continue receiving EITC benefits. They can only choose to work fewer hours. Although some might argue that reductions in work effort of any degree are unacceptable, that argument is likely to be unpersuasive to many: working less is quite different from not working at all. The choice to work, for example, thirty hours a week rather than forty should be much less troubling than the choice not to work, especially in light of the presumptive enhancement of the working poor's wellbeing that results from their free choice to consume more leisure given their enhanced incomes. ${ }^{90}$ Further, the working poor with children under age eighteen - the group that receives the largest EITC benefits - may reap particularly large gains in well-being from having more time for child care. ${ }^{91}$

This analysis does not deny that labor-supply reductions among the poor (and among the richer taxpayers whose higher taxes finance the program) may raise the economic cost of redistribution. However, debates that focus solely on the magnitudes of the EITC's potential work disincentives for EITC recipients are seriously incomplete, even within the framework of a traditional economic analysis. A thorough comparison of the economic effects of different transfer programs would assess both the costs and benefits of redistribution. ${ }^{92}$ Evalua-

87 For data on work by AFDC recipients, see sources cited above in note 52 .

88 One might argue that restricting choices in the short run will improve well-being in the long run by building human capital that creates opportunities for higher earnings and greater social mobility. On the other hand, although a degree of economic paternalism may be warranted in moving welfare recipients into the working world, EITC recipients, who are already at work, may be comparatively well prepared to evaluate their own prospects for future advancement.

89 See supra Part II.

90 But cf. Jon Elster, Is There (or Should There Be) a Right to Work?, in DemocRACY AND THE Welfare STATE, supra note 49 , at 53,63 (arguing, in another context, that a small reduction in hours worked might inflict "cumulative long-term damage" to social relations and to a sense of worth, which would outweigh the short-term gain in leisure). One interesting effect of the EITC's structure is that a decision by an EITC recipient in the phase-in range to work less actually saves the government money; that is, if the income effect is strong enough, she may choose additional leisure at the cost of foregoing extra EITC benefits. Ultimately, the central problem is normative: why should we be troubled if the EITC allows people to work 15 hours a week rather than 40 ? Should we require people to work full-time even if their own preferences would lead them to work less?

91 See Shapiro \& GReEnStein, supra note 8, at 30.

92 For example, a careful analysis might consider not only the receipt of money by EITC recipients, but also the long-term value of work to EITC recipients and to society, as well as the more general benefits of redistribution, including the value of altruistic behavior and of enhanced 
tions of the EITC and other social welfare policies that turn only on the magnitude of work disincentives implicitly judge programs based on costs alone and, as a consequence, incorporate an anti-redistributive bias: if effects on work effort are (implicitly) the principal criterion, less redistributive policies will tend to prevail. Following the logic of these arguments, no redistribution at all would be the best choice, because it would cost the least.

Another explanation for the peculiarity of debates over the EITC and work is that such debates actually reflect unacknowledged normative tensions. Is the goal of the EITC to increase the well-being of the poor, to get the poor to work (even if they are worse off), or to increase gross domestic product (GDP)?93 It may be that critics of the EITC's potential work disincentives really reject the first goal in favor of the second or third, despite their nominal obeisance to the conventions of economic analysis. Although proponents of the latter two goals are likely to find the EITC preferable to traditional welfare programs, these goals actually support other policies: no redistribution at all, or redistribution combined with mandatory work would seem to serve these goals even better. ${ }^{94}$ Of course, if maximizing gross domestic product were truly the objective, mandatory work requirements should apply to the rich and middle class as well as to the poor. The

participation by the poor in community life. See generally Rosen, supra note 56, at I66-67 (enumerating a variety of possible benefits of redistribution). Another possible social benefit of the EITC is that aid to the working poor may alleviate the economic impact of the transition to free trade and integrated world markets, which may put downward pressure on already low wages. See generally Jeffrey N. Gordon, Corporate Governance and the Transition Costs of Capitalism I-4 (Oct. 6, I994) (unpublished manuscript, on file with the Harvard Law School Library) (observing that the law and legal rules can mitigate losses that arise from transitions in capitalist economies). Some studies have attempted to quantify the extent to which economic losses due to labor-supply reductions exceed gains attributable to redistribution, but these studies have taken a rather limited view of the welfare gains attributable to redistribution and count only the disposable income (and leisure) gained by the recipients of transfers. See, e.g., RoberT K. Triest, ThE EfFiciency Cost of INCREASEd Progressivity (National Bureau of Economic Research Working Paper No. 4535, 1993) (estimating that the net cost of an increase in the EITC is as low as $20 \not$ per dollar of transfer); Charles L. Ballard, The Marginal Efficiency Cost of Redistribution, 78 Am. ECON. Rev. ror9, IoIg (I988) (estimating marginal efficiency costs of $50 \not$ to $\$$ I.30 per dollar transferred); Browning \& Johnson, supra note 85, at 199 (finding that people in the top three income quintiles lose $\$ 3.49$ in disposable income, adjusted for the value of leisure, in order to increase the disposable income by one dollar, adjusted for the value of leisure, of those in the bottom two quintiles).

93 The taxonomy, of course, is a rough one. For example, the first two goals are not always easily distinguishable. It may be that the poor will be better off in the long run if they work, and thereby build human capital, despite the short-term loss in utility. In that case, the first two goals may coalesce, if the first goal values long-term well-being more highly than it does short-term well-being. Resolving this issue requires the articulation of a normative ground for preferring long-term over short-term well-being when the two conflict. Another example of ambiguity in this taxonomy is the unspecified nature of "well-being" in the first goal. Amartya Sen, for one, has noted the multiplicity of conceptions of well-being. See SEN, supra note 5I, at 3I-55.

94 See Mead, New Politics, supra note 13 , at $160-62,171$. 
basic point is that, for analytic clarity, critics of work disincentives in the EITC should make their goals explicit and thus open to debate. ${ }^{95}$

A more careful economic evaluation of the EITC should also take into account the magnitude and pattern of redistribution under the EITC and alternative programs. The EITC provides no benefits to nonworkers, little to those who work part-time at very low wages, and quite a bit to those who earn a total amount comparable to full-time work at the minimum wage. Traditional welfare programs, in contrast, typically provide the greatest benefits to nonworkers. Although the distributional effects of the EITC relative to welfare may be of relatively little concern as long as the EITC merely supplements welfare, they will become extremely important if the EITC remains in place while traditional welfare benefits are curtailed. That prospect frames the distributional comparison in the sharpest terms: are we willing to deny income transfers to the poorest nonworkers and their children? To be complete and persuasive, comparisons of labor-supply reductions must be accompanied by careful positive and normative evaluations of distributional patterns.

Finally, any comparison of the economic effects of the EITC and alternative policies should also consider the distributional and incentive effects of the taxes levied to finance the programs. For example, potential reductions in labor supply by taxpayers in response to higher taxes may reduce both total economic output and taxpayers' wellbeing. ${ }^{96}$ These changes represent additional costs of redistribution. Or, for example, the distributive impact of the taxes required to finance the program may either enhance or hinder the redistributive impact of the transfer program. ${ }^{97}$ Taking into account the whole picture - taxes as well as transfers, distribution as well as incentives - can

95 Commentators have noted similar tensions among the goals of "workfare" programs, which may be variously intended to improve the circumstances of the poor, to require work in exchange for welfare benefits even if the work experience does nothing to enhance employment prospects or to save the government money. See, e.g., HANDLER \& HASENFELD, supra note II, at i85-86.

96 Even programs that appear to be financed by budget cuts rather than by new taxes are still financed by "higher taxes" - that is, taxes remain higher (and create potentially greater disincentive effects) than if these programs too were eliminated.

97 Non-income-tested, or "universal" programs illustrate the pitfalls of partial comparisons. Universal programs, such as family allowance programs, pay benefits to all eligible claimants without regard to income. These programs may appear at first to create no work disincentives, because they do not reduce benefits as income rises, and thus may appear to distribute benefits equally to high- and low-income classes. Taking into account the financing side of the picture, however, universal benefits provide to any recipient only a net benefit equal to the gross benefit less her allocable portion of the taxes that finance the program. As a consequence, even a nominally universal program in effect contains an implicit income test, which determines the overall distributional effect of the program and its pattern of work disincentives. See GreEN, supra note 6, at 62-65, I86-87; StAnley S. SuRrey, Statement Before the President's Commission on Income Maintenance Programs, in TAX POLICY AND TAX REFORM: 1961-1969 at 285, 308 (I973); Irwin Garfinkel, Introduction to INCOME-TESTED TRANSFER PROGRAMS: THE CASE For AND AGainst I, 3-4 (Irwin Garfinkel ed., I 982). This analysis still overlooks some important issues 
dramatically change a comparison of alternative programs. The importance of a comprehensive analysis, although axiomatic in public finance theory, is too often forgotten in policy evaluations of the EITC. ${ }^{98}$

\section{B. The EITC "Marriage Penalty": Facing the Realities of Program Design}

Debates over the EITC also reflect concerns about potential marital disincentives in income-transfer programs. Single-parent families, particularly those headed by women, tend to be disproportionately poor and constitute a growing segment of the population. ${ }^{99}$ The causes of poverty among female-headed families are complex, as are the causes of the declining marriage rate. ${ }^{100}$ However, if redistributive programs bolster an existing social trend that contributes to pre-transfer poverty, once again behavioral effects may raise the cost of redistribution. Despite popular stereotypes, empirical studies suggest that welfare has contributed little to the growth in the number of singleparent families. ${ }^{101}$ Nevertheless, the perceived effects of marital disincentives in welfare programs continue to play a significant role in both popular and academic discussions of welfare policy. ${ }^{102}$

EITC advocates point out that, unlike welfare, the EITC is fully available to two-parent families. ${ }^{103}$ Critics of the EITC argue that the

(for example, how to identify the "marginal" taxes associated with a given transfer program), but it illustrates an important conceptual point.

98 A recent study by Robert Triest illustrates the importance of this point. Triest initially concludes that the net efficiency cost of an increase in the EITC is quite low compared to the cost of alternative programs, but he then finds that, if the alternative programs are compared to a modified EITC that achieves a similar distributional pattern, the efficiency differences disappear. See TRIEST, supra note 92, at 22.

99 See 1994 GREen Book, supra note 2, at I I I , II6I.

100 Garfinkel and McLanahan attribute poverty among female-headed families to three factors: low earnings (relative to those of men), a lack of support from noncustodial parents, and meager government benefits. See Garfinkel \& MCLANAhan, supra note 64, at I 7 . For a discussion of reasons for a declining marriage rate, see Robert D. Mare \& Christopher Winship, Socioeconomic Change and the Decline of Marriage for Blacks and Whites, in THE URBan UNDERCLASS I75, 175-202 (Christopher Jencks \& Paul E. Peterson eds., I991).

101 The number of single-parent families has grown while welfare benefits have declined in real terms, and single parenthood has increased among all income classes. See MARY J. BANE \& David T. Ellwood, Welfare Realities: From Rhetoric to Reform i I I-I 2 (ig94); David T. Ellwood \& Lawrence H. Summers, Poverty in America: Is Welfare the Answer or the Problem?, in Sheldon H. Danziger \& Daniel H. Weinberg, Fighting Poverty, at 78, 92-97 (I986); Moffitt, supra note 52, at 30-3I.

102 Handler and Hasenfeld describe the longstanding American tradition of hostility and suspicion toward single mothers. See HANDLER \& HASENFELD, supra note II, at 60-74, 103-05. For a critique of cultural stereotypes that blame single mothers for poverty, see Martha A. Fineman, Images of Mothers in Poverty Discourses, I99I DukE L.J. 274, 274-89.

103 See, e.g., I39 CoNG. REc. $\mathrm{H}_{5532}$ (daily ed. July 30, 1993) (statement of Rep. Bill Richardson). In contrast, AFDC typically enables single parents to obtain aid more easily than can twoparent families. Although all states must now provide some benefits to two-parent families with 
program, is nevertheless biased against marriage, because it creates "marriage penalties" that may discourage poor workers from marrying (or may encourage them to divorce). ${ }^{104}$ Although understanding potential disincentives is useful, it is crucial to remember that they do not translate automatically into behavior. A firm conclusion must await empirical evidence, but at the outset it seems at least as plausible to expect that the EITC (like welfare) has little effect on family structure as to predict a dramatic impact. ${ }^{105}$ For example, the EITC's potential disincentives may be blunted by the numerous psychological, social, and economic factors that influence marital decisions and by EITC recipients' apparently limited understanding of the terms of the program. ${ }^{106}$

Further, critiques of the EITC's marital disincentives fail to confront the policy trade offs inherent in designing the EITC or any other redistributive program. Marriage penalties are a virtually unavoidable characteristic of income transfers that tailor benefits to need. Although it is in theory possible to redesign income-tested transfer programs to avoid penalizing marriage, the necessary changes would compromise policy goals that many may find more important than marriage neutrality. ${ }^{107}$

Marriage penalties arise from the need to tailor EITC (or welfare) benefits to need. Theorists generally agree that the aggregate income of the family provides a better measure of economic status than individual income. For example, consider two individuals, each with no income or assets. Measuring the income of each individual alone

an unemployed principal earner, benefits may be available only for part of the year, and eligibility conditions can exclude many two-parent families, for example, if the principal earner works 100 hours a month or more or has no established work history. See 42 U.S.C. $\$ 607$ (I988 \& Supp. V I993); 45 C.F.R. § 233.IOI (I993).

104 See, e.g., Colin D. Campbell \& William L. Peirce, The Earned Income Tax Credit I I-I 2 (I980); Francine J. Lipman \& James E. Williamson, Recent Proposals to Redesign the EITC: A Reply to an Economist's Response, 62 TAX NoTES I I75, II79 (I994); Edward J. McCaffery, Taxation and the Family: A Fresh Look At Behavioral Gender Biases in the Code, 40 UCLA L. REV. 983, 995 (1993).

105 McCaffery and Scholz are sensitive to the empirical issue. McCaffery argues that the EITC marriage penalty occurs "at exactly the point where legally sanctioned marriages might be most sensitive to economic conditions." McCaffery, supra note 104, at 1016. Scholz notes the absence of empirical evidence and suggests that the EITC will provide an opportunity for examining the effects of income transfers on marital status. See John K. Scholz, Tax Policy and the Working Poor: The Earned Income Tax Credit, i5 Focus I, Io (1993-1994).

106 See, e.g., Olson with DAvis, supra note 55, at $12-13$.

107 This "marriage penalty" arises when a couple is better off, in the aggregate, by remaining unmarried (or divorcing) rather than marrying (or remaining married). Critics of redistributive programs sometimes point to a second type of potential disincentive for marriage. By providing a source of support for women outside of marriage, income-transfer programs may make divorce easier and therefore more likely. These critics' focus on marital breakups overlooks the positive effects of enabling women to leave mentally or physically abusive or otherwise unproductive marriages. 
would suggest that the two individuals have an equal need for transfer benefits. The comparison is misleading, however, if one is a minor child in a family with a comfortable annual income and the other is the unemployed principal earner in a family with no other source of income. For this reason, both income-transfer programs and the federal income tax typically seek to award benefits or to assess taxes based on family incomes. ${ }^{108}$

Although measuring family income tends to promote (relatively) accurate income measurement, it typically does so at the expense of marriage neutrality in the EITC and in other income-transfer programs tailored to need. The problem arises because these programs typically create "regressive" patterns of marginal tax rates - that is, benefit reduction rates that typically exceed the marginal income tax rates applicable to those taxpayers with incomes just above the program's income cutoff. ${ }^{109}$ The dilemma for the EITC and other income-transfer programs is that they cannot simultaneously maintain regressive marginal tax rates, equal treatment of families with equal incomes, and marriage neutrality. Any system can have two, but not all three of these characteristics. ${ }^{110}$ Only a system of constant (flat) marginal tax rates could achieve both equal treatment of families and marriage neu-

108 See, e.g., Boris I. Bittker, Federal Income Taxation and the Family, 27 STAN. L. REv. I389, 1392-93 (1975); Pamela B. Gann, Abandoning Marital Status as a Factor in Allocating Tax Burdens, 59 TEx. L. Rev. I, 25 (1980); William A. Klein, Familial Relationships and Economic WellBeing: Family Unit Rules for a Negative Income Tax, 8 HARV. J. ON LEGIS. 36I, 370 (I97 I). For a discussion of the family unit rules in AFDC, Food Stamps, and SSI, see 1994 GREEN Book, cited above in note 2 , at $327,762-63,217-18$; and OHLS \& BEEBOUT, cited above in note 64 , at 21-25. For a discussion of the family unit rules of the federal income tax, see Part IV.B below.

109 See Graph 3, supra p. 550; Table 3, supra p. 550. For example, an EITC recipient may face an EITC phase-out rate of $2 \mathrm{r} \%$, a payroll tax rate of nearly eight percent, and, simultaneously, a $15 \%$ marginal federal income tax rate for a cumulative marginal rate of $44 \%$, but a worker with income just above the EITC income cutoff faces only the eight percent payroll tax and the $15 \%$ marginal income tax rate for a cumulative marginal rate of $23 \%$. The regressive pattern of marginal tax rates is characteristic of income-tested transfer programs. See Garfinkel, supra note 97 , at 4 .

110 Consider a simple income-transfer program with a maximum benefit of $\$ 5000$, a benefit reduction rate of $25 \%$, and (therefore) an income cutoff of $\$ 20,000$. Assume that the income tax system imposes tax at a rate of $0 \%$ on income less than or equal to $\$ 20,000$ and at a marginal tax rate of $15 \%$ on income that exceeds $\$ 20,000$. Consider four individuals:

\begin{tabular}{crrr} 
Name & \multicolumn{2}{c}{ Income } & Tax (single) \\
A & $\$$ & 0 & $-\$ 5,000$ \\
B & $\$ 30,000$ & $+\$ 1,500$ \\
C & $\$ 15,000$ & $-\$ 1,250$ \\
D & $\$ 15,000$ & $-\$ 1,250$
\end{tabular}

If $A$ and $B$ marry and $C$ and $D$ marry, an income-support program that preserves marriage neutrality would leave unchanged the aggregate taxes (positive or negative) paid by each couple. That system, however, would treat the two equal-income couples very differently. The $A / B$ couple would receive a net benefit of $\$ 3500$, but the $B / C$ couple would receive a net benefit of only $\$ 2500$. Adjusting the rate schedule so that both couples receive the same net benefit would necessarily impose a marriage bonus or penalty on one or both couples. For an analogous demonstration in the context of the income tax, see Bittker, cited above in note I08, at I395-96. 
trality. ${ }^{111}$ In essence, aggregation of family income in an income-tested transfer program makes marriage neutrality impossible. ${ }^{112}$ Critics of the EITC's marriage penalty typically overlook the roots of such penalties in the very structure of income-transfer programs. ${ }^{113}$

The design of the EITC exacerbates this inherent marriage penalty. The EITC is available to both single-parent and married-couple families, but the amount of the credit is the same for single parents and for married couples that have the same income and number of children. Thus, a married couple earning $\$ 28,000$ receives no EITC, but two single people, each earning $\$ 14,000$, may each receive a substantial EITC. ${ }^{114}$ As a consequence, the EITC can impose huge marriage penalties, particularly relative to income. ${ }^{115}$ In certain other cases, however, it can actually award marriage bonuses. ${ }^{116}$ This aspect of the EITC's marriage penalty could be eliminated by modifying the EITC, but at the cost of either cutting benefits for single parents or

111 See Jonathan R. Kesselman, Taxpayer Behavior and the Design of a Credit Income Tax, in InCOMe-Tested Transfer Programs, supra note 97, at 216-17, 222-23.

112 A similar dilemma occurs within the federal income tax system. An income tax system cannot simultaneously maintain progressive marginal tax rates, equal taxation of families with equal incomes, and marriage neutrality. See, e.g., Bittker, supra note 108, at I395-96; Rosen, supra note 56, at 402-04. Federal income tax policy has wrestled with this dilemma and has adopted different compromises over the years. See, e.g., Bittker, supra note 108, at 1399-1416, 1428-31; Gann, supra note 108, at 10-24.

113 A marriage penalty may arise even in an income-transfer program that provides benefits to married couples equal to twice the benefits available to a single person with the same income. Consider what happens if, in the example in note I Io above, the income-transfer system provides married couples with a basic benefit of $\$ 10,000$, phased out at $25 \%$, with an income cutoff of $\$ 40,000$. In that case, the $A / B$ and $C / D$ couples each receive a benefit of $\$ 2500$, which is marriage neutral as to $C / D$ but penalizes $A / B$.

The examples in this Article highlight the structural roots of marriage penalties in income taxes and transfers. Actual marriage penalties or bonuses for EITC recipients are determined by the complex interplay of several factors, including the regressive marginal tax rate structure created by the juncture of the EITC's phase-out rate and the first income tax bracket, the potential marriage penalty created by awarding the same EITC benefits to married couples and single individuals with the same income, and the marriage bonuses and penalties of the federal income tax system.

114 In I996, a married couple with two children and earnings (and total income) of $\$ 28,000$ (in I 994 dollars) will receive no EITC. If, however, the couple divorced, each obtained custody of one child, and each had post-divorce earnings of $\$ 14,000$, each person would receive an EITC of about $\$ 156 \mathrm{I}$, for an aggregate gain of $\$ 3 \mathrm{I} 22$. This example ignores the federal income tax and, of course, the non-tax costs of divorce. Although this example illustrates how large EITC marriage penalties can be, the assumption that each parent obtains custody of one child may be unrealistic.

115 As a percentage of earnings, the EITC marriage penalties are among the largest imposed in the federal income tax system. See CBO, supra note 10, at 37-40.

116 The EITC's marriage bonus arises if, for example, a childless worker marries a nonworker with children: in that case, the couple may receive a higher EITC than if the individuals remain unmarried. This analysis may overstate the net marriage bonus to the extent that the custodial parent loses AFDC or other benefits. 
raising benefits for married couples. ${ }^{117}$ Even such a modified EITC, however, would still face the marriage penalties or bonuses inherent in an income-tested transfer program with regressive marginal tax rates. ${ }^{118}$

In theory, the EITC or any income-tested transfer program could be restructured so that it awarded only marriage bonuses and never marriage penalties. The resulting pattern of benefits, however, would probably strike many as undesirable. For example, one of the strangest consequences would be the payment of EITC benefits to relatively high-income married couples. To understand why, imagine a middle-class couple with two children and total earnings of $\$ 50,000$. In a hypothetical worst-case scenario (worst case for the Treasury, that is), if this couple divorced, one would gain custody of both children and would have earnings that qualify for the maximum EITC. To avoid creating any incentive to divorce, we would have to award the maximum EITC to the intact couple, reduced to reflect the loss of the federal income tax marriage bonus for couples with disparate earnings. ${ }^{119}$ Many policymakers would probably accept some EITC marriage penalty in order to keep the program targeted more closely to the poor.

A similar but analytically distinct alternative is to award the EITC to each worker based on her earnings alone, regardless of marital status. Under this system, by definition, a change in marital status would

117 For example, suppose that a married couple with two children remained entitled to a maximum EITC of $\$ 3370$ based on the current terms of the program. At the same time, however, suppose that the benefit schedule for a single parent were changed so that it contained the same earnings subsidy and phase-out rates (40\% and $21.06 \%$, respectively), but all dollar thresholds were half as much (maximum EITC of $\$ 1685$, reached at earnings of $\$ 4,212.50$, with phase-out beginning at earnings of $\$ 5500$, and an income cutoff of $\$ 13,500$ ). In that case, the EITC would create neither a marriage bonus nor a marriage penalty for a couple earning $\$ 14,000$ each.

118 Continuing the example from note II 3 above, consider a couple with two children, one person earning $\$ 6000$ and one earning $\$ 24,000$. If married, they would not be entitled to any EITC and would pay federal income tax of about $\$ 2078$. If the couple divorced and the lower earner obtained custody of both children, he would receive an EITC (under the modified program described in the preceding note) of about $\$ 1580$ and pay no federal income tax, while the higher earner would pay about $\$ 2663$ in federal income tax. The net tax gain from divorce to the couple would be $\$ 995$ (old tax liability of $\$ 2078$ less new tax liability, net of EITC, of $\$ 1038$ ). (The example uses 1994 tax rates.)

119 For example, assume that John and Mary, a married couple with two children, jointly earn $\$ 50,000$. John earns $\$ 10,000$, and Mary earns $\$ 40,000$. Filing jointly in 1994, John and Mary will owe federal income taxes of $\$ 5078$. If, instead, John and Mary divorce, and John receives custody of the two children, he will be entitled to an EITC of $\$ 3370$ and will owe no federal income taxes, and Mary will owe federal income taxes of $\$ 6823$. Thus, the couple's total tax bill falls to $\$ 3453(\$ 6823-\$ 3370)$ if they divorce, which creates a marriage penalty (or higher tax bill) of $\$ 1625$ (\$5078 - \$3453). To remove the marriage penalty, John and Mary should be entitled, as a married couple, to an EITC of $\$ 1625$. (Note that this solution removes the marriage penalty that the EITC creates in order to avoid creating a potential incentive for divorce. In the absence of the EITC, upon divorce, John would owe no tax, and Mary would owe tax of $\$ 6823$; that is, in the absence of the EITC, there would be a marriage bonus to John and Mary of $\$ 1745$.) 
not decrease (or increase) EITC benefits. This proposal, however, simply illustrates once again the trade off described above: awarding the EITC based on individual income avoids creating a marriage penalty but does so by eliminating the tailoring of benefits to need based on family income. As a consequence, even high-income families could qualify for the EITC. For example, a family in which the husband earns $\$ 10,000$ and the wife earns $\$ 200,000$ could qualify for the maximum EITC benefit. ${ }^{120}$ Similarly, although awarding the EITC based on separate incomes avoids creating a marriage bonus, it would create disparities in treatment by awarding the EITC to some, but not all families with the same level of high earnings. ${ }^{121}$ Thus, the EITC, like other income-tested transfer programs, creates unavoidable and difficult policy trade offs between potential marital disincentives and accurate targeting of benefits.

\section{INSTitutional Limitations OF THE EITC AND OTHER TAX- Based TRANSFer Programs}

The conceptual link between income-transfer programs and the income tax has fascinated economists and policy analysts for years. Advocates of the negative income tax and, more recently, of the EITC have proposed administrative integration of the tax and transfer systems as a route to welfare reform. ${ }^{122}$ These analysts point to two principal advantages of tax-transfer integration. First, proponents argue, the EITC and other tax-based transfers can enhance administrative

120 The exact dollar benefit would depend on the number of children in the family and how they were grouped with the two parents for EITC purposes.

121 In addition, identifying separate incomes for EITC purposes alone could be difficult, because the federal income tax is structured to measure joint incomes. Couples would face obvious incentives to shift income and to reallocate itemized deductions in order to maximize the EITC. For a discussion of administrative issues under an income tax with individual filing, see Alicia $\mathrm{H}$. Munnell, The Couple Versus the Individual Under the Federal Personal Income Tax, in THE Economics of TAXation 247, 273-77 (Henry J. Aaron \& Michael J. Boskin eds., I980).

122 It is important to distinguish between tax-transfer integration (administering transfer programs through the tax system) and consolidation (replacing various tax and transfer programs with a single program). The negative income tax plans of the rg6os and r 970 s typically featured both integration and consolidation, usually by replacing a variety of traditional transfer programs with a single tax-based transfer program. In some cases, however, negative income tax plans contemplated administration through a welfare agency rather than through the tax system. See SURREY, supra note 97 , at $3^{\mathrm{I} 2-\mathrm{I} 3}$ (comparing administration of a negative income tax by the Internal Revenue Service and by other agencies). For more recent examples of tax-transfer integration and consolidation, see RoBert HAVEman, STARTING Even 156-58 (r988), which proposes tax credits to replace AFDC, SSI, food stamps, and housing assistance; and Jonathan B. Forman, Administrative Savings From Synchronizing Social Welfare Programs and Tax Provisions, $13 \mathrm{~J}$. NAt'L Ass'N Admin. L. Judges 5, 64-72 (I993), which advocates a system of refundable tax credits to replace many current programs. The EITC, on the other hand, attempts only taxtransfer integration, and that is my focus here. 
efficiency by reducing bureaucratic cost and complexity. ${ }^{123}$ Welfare administration is labor-intensive, expensive, and heavily dependent on "street-level" bureaucrats, who may administer programs in a manner at odds with their formal terms. ${ }^{124}$ In contrast, tax-based transfers like the EITC make use of the existing institutions of the federal income tax and thus are cheaper to administer. ${ }^{125}$

Second, advocates claim, tax-based transfers can reduce the stigma and social isolation associated with welfare. David Ellwood, for example, argues that, under the EITC, "[p]eople are helped without any need of a stigmatizing, invasive, and often degrading welfare system, and their autonomy is increased, not decreased. Since [the EITC] truly would be part of the tax system .... , people would not be isolated."126 Tax-transfer integration may also enhance the EITC's political appeal: Theda Skocpol argues that, because the EITC is administered through the tax system, "in which all workers participate," the EITC is more like a politically acceptable universal program than a politically unsustainable targeted program. ${ }^{127}$

The idea of tax-transfer integration thus combines administrative, humanitarian, and political goals. Despite its surface appeal, however, the case for tax-transfer integration is less compelling than its propo-

123 See, e.g., American Enter. Inst., The Administration's 1979 Welfare Reform ProPOSAl 27 (I979); EllwOOD, supra note 8, at II4; Organisation FOR ECONOMIC Co-OPERATION and Dev., Negative Income Tax i2 (1974).

On the other hand, a recent study suggests that a significant portion of EITC recipients pay commercial tax preparers substantial sums to prepare their returns and rely on preparers to determine eligibility and amount of benefits. See Olson wITH Davis, supra note 55, at I3 n.I6 (citing a survey of New Jersey families indicating that two-thirds of those who applied for the EITC paid someone to do their taxes and describing the fees paid). Additional evidence confirming that EITC recipients generally use commercial tax preparers would call into question the extent to which tax-based administration is as nondiscretionary and automatic as it appears, and further inquiry into the performance of these private-sector "case workers" would be appropriate.

124 See generally Michael LipSKy, STREET-LeVEl BUREAUCRACY I3-25 (1980) (arguing that street-level bureaucrats effectively make agency policy).

125 In 1992, the costs of administering the federal income tax were around one percent of revenue raised, compared to administrative costs of ${ }_{13} \%$ of benefits in the case of AFDC and 10\% of benefits in the case of SSI. The cost of programs that are not income-tested can also be quite low: the administrative cost of Social Security was typically one to two percent of benefits paid. See Forman, supra note 122, at 34-35 (citing House COMM. ON WAYS AND MEANS, 102D Cong., 2D Sess., Overview of Entitlement Programs: 1992 Green Book, 82, 654, 823 (Comm. Print I992)).

126 EllwoOd, supra note 8, at II5; see also HANDLER \& HASENFELD, supra note II, at I60 ("To receive the tax credit one must file a federal tax return, a symbol of an earned economic citizenship."); Phoebe H. Cottingham, Introduction to Welfare Policy fOR THE 1990s, supra note 18 , at I, 9 (noting that non-welfare strategies, including refundable tax credits, "will have less of a labeling effect than do welfare policies"); $c f$. JoHN E. Schwarz \& Thomas J. Volgy, The Forgotten AMERICANS I42 (I992) ("The new program [of tax credits], implemented through the privacy of the normal tax system, would remove th[e] stigma [associated with traditional transfers].").

127 Theda Skocpol, Targeting Within Universalism: Politically Viable Policies to Combat Poverty in the United States, in THE URBan UNDERCLASS, supra note roo, at $4 \mathrm{II}, 43 \mathrm{I}$. 
nents claim. The EITC illustrates the institutional dilemmas that inevitably arise in tax-based transfer programs that tailor benefits to need. ${ }^{128}$ Further, these inherent limitations of tax-based transfer programs suggest that there may be sound reasons to tolerate the conceptual and administrative untidiness of separate tax and transfer systems. ${ }^{129}$ More empirical and comparative work is needed to assess the relative merits of the EITC. Advocates of the EITC and similar tax-based transfers, however, should realize that these programs will not be widely acceptable unless we moderate our expectations about the goals such transfers can achieve.

Throughout this analysis, my focus is on identifying the inherent structural limitations of the EITC and other tax-based programs. ${ }^{130}$ I do not attempt a comprehensive treatment of all issues of implementation - for example, questions of forms, procedures, or exactly how alternative rules defining "income" or "family" might work. These questions have been addressed by others ${ }^{131}$ and are not my concern here. Indeed, one theme in this Part is that analyses concerned only with particular issues of EITC administration sometimes overlook the structural features that create those problems and make those problems resistant to reform.

\section{A. Understanding the Inherent Limitations of Tax-Based} Programs: The Importance of Income Measurement in the EITC

The task of income measurement is fundamental to both income tax and income-transfer systems. Both systems seek to assess economic well-being, using income as a proxy, in order to apportion tax

128 The analysis in this Part applies to the EITC and to other income-tested, tax-based transfers but does not necessarily apply to non-income-tested, tax-based transfers, which award benefits without regard to income. A subsequent Article will address the applicability of this analysis to non-income-tested programs. See infra Part V.

129 This Article focuses on the costs of the EITC's tax-based administration and does not attempt to analyze or to quantify the claimed administrative and other advantages of tax-based programs, such as the reduction in administrative costs or the alleviation of stigma. This Article does argue, however, that an analysis of the claimed administrative savings should take into account the limitations described here: for example, is a tax-based program really "cheaper" if these institutional constraints hinder its performance?

130 The analysis in this Part draws on a body of excellent work on institutional aspects of the negative income tax. See GreEN, supra note 6, at 82-II2; Michael R. Asimow \& William A. Klein, The Negative Income Tax: Accounting Problems and a Proposed Solution, 8 HARV. J. ON LEgIS. I (I970); William A. Klein, The Definition of "Income" Under a Negative Income Tax, 2 Fla. St. U. L. Rev. 449 (I974); Klein, supra note 108; William D. Popkin, Administration of a Negative Income Tax, 78 YAlE L.J. 388 (I969); James Tobin, Joseph A. Pechman \& Peter M. Mieszkowski, Is a Negative Income Tax Practical?, 77 Yale L.J. I (I967).

131 See, e.g., Janet Holtzblatt, Administering Refundable Tax Credits: Lessons From the EITC Experience, in 84 National Tax Association - Tax Institute of America Proceedings I80, I8I-83 (I99I); George K. Yin, John K. Scholz, Jonathan B. Forman \& Mark J. Mazur, Improving the Delivery of Benefits to the Working Poor: Proposals to Reform the Earned Income Tax Credit, I I AM. J. TAX PoL'y 225, 260-94 (I994). 
burdens and income-transfer benefits appropriately. Much legal scholarship on tax policy addresses ways to make more precise the definition of income. Analogous issues confront social scientists who attempt to measure income for statistical purposes. ${ }^{132}$ Analytically, the problem of income measurement consists of at least four issues: How should income be defined? How should we group individuals into families for purposes of measuring income? Over what period should we measure income? What steps should we take to ensure compliance with the income measurement rules we establish? Answering each question requires some compromise among important objectives, and, not surprisingly, the existing income tax and transfer systems often strike different balances.

The divergence between the two systems may at first seem unwarranted: why should the tax and transfer systems adopt different measures of income? In theory, the two income measures should be the same, because both systems seek to assess economic resources accurately to determine the contribution to be made to or received from society. The unified tax-transfer model illustrated in Part $\mathrm{II}^{133}$ becomes impossibly muddled if the measures of income used in the tax and transfer systems are not comparable.

This view is too simple, however. The analysis in this Part shows that the different approaches to income measurement in the tax and transfer systems may well be defensible, even productive, responses to the different goals and characteristics of each system. This argument challenges the easy case for tax-transfer integration by showing that there may be reasons to maintain separate systems. Traditional transfer programs and tax-based transfer programs face similar trade offs among important goals in measuring income. Each system, for example, must balance the desirability of a comprehensive definition of income against the cost of administering such a definition. The tax and transfer systems have, over time, struck different compromises in response to these trade offs. Consequently, any transfer program that adopts the tax system's rules and procedures necessarily strikes a different balance than traditional transfer programs do. Further, these different institutional choices make tax-based programs less accurate in tailoring benefits to need, less responsive to changing needs, and less

132 See, e.g., Staff OF the Joint Comm. ON TAXation, supra note 29, at 82-99; Robert Haveman, Poverty Policy and Poverty Research 57-66 (ig87); Patricia Ruggles, Drawing the Line: Alternative Poverty Measures and Their Implications for Public PolICY 89-I62 (I990).

133 See Graph 2, supra p. 543; supra note $4 \mathrm{I}$. If existing tax institutions foster inaccuracy, unresponsiveness, and noncompliance, why do they remain acceptable for tax purposes? Tracing the historical, political, and other reasons for divergence in the tax and transfer systems is beyond the scope of this Article. A historical explanation is also unnecessary to my argument, which is based on a description of current institutions: although a hypothetical tax system could easily accommodate tax-transfer integration, our current system would require major changes to do so. 
capable of enforcing compliance than their traditional counterparts. The fundamental dilemma of tax-transfer integration is that reforms to alleviate these limitations necessarily require either compromising taxtransfer integration or undertaking wholesale reform of the tax system. For example, although in theory the tax system might adopt the more comprehensive definitions of income characteristic of traditional income transfer programs, such a change in the tax law would be disruptive, expensive, and probably politically unacceptable. Alternatively, the tax system might adopt separate, welfare-like rules and procedures solely for purposes of a tax-based transfer program, but that approach would tend to undermine the purported advantages of integration. ${ }^{134}$

A recognition of these dilemmas does not require the rejection of the EITC or other tax-based transfer programs, but it does caution against assuming that tax-based programs are uncomplicated or unquestionably desirable. Implementing the "simple" vision of an integrated tax and transfer system would require radical and costly changes in the tax system - changes the advocates of tax-transfer integration rarely discuss.

One might question whether these income-measurement criteria are appropriate for evaluating the EITC. If we view the EITC as an earnings subsidy - intended only to "make work pay" - rather than as a traditional transfer program, perhaps these limitations are unimportant. For example, inaccuracy in awarding EITC benefits may be less troubling if the goal is to encourage work rather than to provide benefits to a sharply defined group of very poor recipients, as with welfare. After all, the EITC already differs significantly from traditional welfare programs in that it provides nothing to nonworkers and little to those with very low earnings. One might argue that the appropriate analogues are the minimum wage and macroeconomic policies aimed at full employment; those policies, like the EITC, also promote welfare objectives by increasing the earnings capability of the poor, but we do not evaluate them using the same criteria we apply to welfare programs. ${ }^{135}$

The assertion that the EITC is a work incentive program that should not be evaluated using income measurement criteria raises serious questions about the proper gauge of performance for public policies, but the premise is slightly too simple. The EITC, as we now know it, serves more than one purpose. ${ }^{136}$ It is an earnings subsidy,

\footnotetext{
134 See infra pp. $574,583$.

$135 \mathrm{I}$ am indebted to Joel Handler for raising this important issue.

136 Cf. Theodore R. Marmor, Jerry L. Mashaw \& Philip L. Harvey, america's MisunDERSTOOD WELFARE STATE 222-28 (I990) (arguing that social welfare programs do not have unitary purposes). Steuerle and Wilson noted some of the multiple purposes of the EITC in a I 988 article and observed that, if the EITC is welfare, it falls short in some important ways. See
} 
intended to encourage work among the poor. The EITC is simultaneously, however, a redistributive program that provides income support for the working poor, under income-testing rules that purport to target the assistance to low-income families. This dual aim is, ostensibly, the EITC's advantage over the minimum wage and other broadly-targeted policies: the EITC holds out the promise of stimulating work while providing extra earnings only to those who really need them. ${ }^{137}$ The EITC's redistributive goals suggest that traditional concerns about accuracy, responsiveness, and compliance have an important place in assessing the benefits and costs of the EITC's tax-based administration. ${ }^{138}$ In other words, although it is possible to conceive of the EITC as purely an earnings subsidy, with few pretensions to redistributive accuracy, responsiveness, or compliance, the EITC has not in fact been designed or promoted in that manner. Particularly in the I990s, as the EITC has expanded beyond its traditional role as an offset to payroll taxes, its income-support function has become increasingly significant. ${ }^{139}$

Eugene Steuerle \& Paul Wilson, The Taxation of Poor and Lower-Income Workers, 21 ClearingHOUSE REV. 1047, I054-55 (1987).

137 See, e.g., BANE \& EllWOOD, supra note IOI, at 149-50.

138 Of course, concerns of accuracy and responsiveness may not be as important in the EITC as in welfare. EITC recipients, by definition, have at least some wage income and thus may be in less dire need than some welfare recipients. In addition, the current EITC awards a significant portion of its benefits to families with incomes higher than those of welfare recipients. See Scholz, supra note 62 , at 77 . On the other hand, some EITC families are as poor as some welfare recipients and others still have relatively low incomes, so that the income support the EITC provides may be crucial for basic necessities. See, e.g., Changes to EITC Could Alleviate Homelessness, Council Says, 33 Tax Analysts' Daily Tax Highlights \& Documents 2519, 2520 (I994). To the extent that future welfare reforms limit access to other sources of support, the accurate and responsive delivery of the EITC may become even more important.

139 The legislative history of the EITC shows that its redistributive function has been important since its enactment. The early legislative history of the EITC describes the program largely as a work incentive and as an offset to payroll taxes but also clearly anticipates that the EITC will be targeted to low-income families. See, e.g., S. PRT. No. 169, vol. I, 98th Cong., 2d Sess. 859 (1984); S. REP. No. 1263, 95 th Cong., 2 d Sess. $5 \mathrm{I}-52$ (1978), reprinted in 1978 U.S.C.C.A.N. 676I, 6814-I5 (noting that the EITC is targeted to "low-income families who might otherwise receive large welfare payments"); S. REP. No. 36, 94th Cong., Ist Sess. 33 (1975), reprinted in I975 U.S.C.C.A.N. 54, 83-84 (indicating that the EITC should be targeted to low-income individuals because encouraging work should help reduce the welfare rolls).

Amendments to the EITC in 1990 increased the credit's redistributive function by raising the EITC to a level that exceeded federal payroll taxes and by adjusting the EITC for family size. These amendments recognized (in part) the different income support needs of families of different sizes. See Omnibus Budget Reconciliation Act of 1990, Pub. L. No. ror-508, \$IIIII, I04 Stat. I388, I388-408 to -4I3, amended by Omnibus Budget Reconciliation Act of I993, Pub. L. No. 103-66, \& I3131, I07 Stat. 312, 433-35 (1993) (codified at I.R.C. § 32 (I988 \& Supp. V 1993)); I.R.C. $\S 3$ IOI(a), (b) (I988) (mandating a payroll tax of $7.65 \%$ for 1990 , a percentage less than the credit percentages provided in the 1990 Act). The legislative history of the EITC since 1990 also characterizes the program as a work incentive but emphasizes even more strongly the income support aspects of the program. See, e.g., H.R. ReP. No. III, I03d Cong., Ist Sess. 609 (1993), reprinted in 1993 U.S.C.C.A.N. 378, 840; H.R. REP. No. 881, Iorst Cong., 2d Sess. 279 (1990), 
Further, even if we could agree to evaluate the EITC only as an earnings subsidy, it is not clear that these income-measurement criteria would be much less important. Ideally, the EITC earnings subsidy should accurately reach the low-income workers (and potential workers) it is intended to motivate. An earnings subsidy also should be responsive in order to transmit its incentives effectively. ${ }^{140}$ Compliance is crucial as well, because the earnings subsidy will not produce the intended behavioral effects if it is available, for instance, to nonworkers who falsely claim earnings.

The question of the appropriate criteria for judging the EITC does, however, underscore the importance of evaluating the EITC in relation to other institutions. The EITC is part of a larger social welfare system that provides other means of ensuring responsive assistance to poor families. Accordingly, the accuracy and responsiveness of the EITC may be of somewhat less concern than if it were the sole form of income support available to the poor. The corollary, however, is that, as the EITC expands to assume a larger role in U.S. social welfare policy, these concerns are likely to grow in importance. Plans for welfare reform may put even greater weight on the redistributive function of the EITC by eliminating other social welfare programs. My point is not that the EITC must maximize responsiveness, accuracy, and compliance. Instead, as Part V discusses, we may choose to scale down our expectations of the EITC and recognize that its virtues come at a price. This normative shift, however, would be a significant one.

\section{B. The Conflict Between Tax-Transfer Integration and Accurate Measurement of Need}

Definitions of "income" and "family" are fundamental to the task of income measurement. The income definition determines which items are counted. The more comprehensive the income definition, the better a proxy "income" is for "economic resources." The family definition controls whose income is counted in evaluating the economic resources of a household. Completely accurate definitions of either "income" or "family" would require individualized determinations, ${ }^{141}$ which would be prohibitively costly. Consequently, both income tax and income-

reprinted in 1990 U.S.C.C.A.N. 2017, 228I; 136 CoNG. REC. Si5629, Si5684-85 (daily ed. Oct. I8, I 990).

140 See infra Part IV.C.

141 For example, a comprehensive measure of income would include the imputed rental value of an owner-occupied home. Because real estate is unique, however, the imputed rental value of each home would have to be determined separately, as would the deductible costs of maintenance and depreciation. Similarly, determining the true "family" unit based on resource-pooling and expense-sharing would require a personalized inquiry into family finances and actual spending patterns. 
transfer systems adopt standardized definitions and sacrifice some precision for administrative savings. The federal income tax system adopts definitions of income and family that are narrower than those used in income-transfer programs and so tends to measure income with less accuracy. ${ }^{142}$ Therefore, the trade off between accuracy and administrative costs takes on a new twist in the EITC and other taxbased transfer programs. In determining the proper trade off, these programs are constrained by the compromises already built into the federal income tax system. Thus, the claimed pecuniary and dignitary advantages of tax-transfer integration come at the expense of adopting the inaccurate rules of the federal income tax.

I. Defining "Income." - Income as reported for federal income tax purposes understates "economic" income in important ways. ${ }^{143}$ For example, the income definition excludes certain fringe benefits, imputed income from property and services, interest on obligations of state and local governments, and a significant portion of income from capital investments. ${ }^{144}$ In addition, the income tax does not measure wealth and so cannot comprehensively assess total economic resources. ${ }^{145}$ The current EITC phases out benefits using the tax code's definition of income (with minor modifications) and does not incorporate a wealth requirement of any kind. ${ }^{146}$ As a consequence, taxpayers with significant wealth or excludable capital income may qualify, quite

142 See infra notes $164-167$ and accompanying text.

143 There are several definitions of "income" for federal income tax purposes. See I.R.C. § 6I (r 988) (gross income); id. $\$ 62$ (rg88 \& Supp. V r 994) (adjusted gross income); id. $\$ 63$ (rg88\& Supp. V r 1993) (taxable income). Even gross income, the broadest measure, falls well short of economic income.

144 See, e.g., id. § 103 (1988); id. § 105 (1988 \& Supp. V r993); id. § I32 (I988 \& Supp. V 1993). The exclusion of the imputed rental value of owner-occupied housing and other consumer durables is not made pursuant to any Code section but is embedded in the tax law as administered. See Marvin A. Chirelstein, Federal Income Taxation 23 (1994). The federal income tax law's definition of gross income often dramatically understates income derived from capital, for example, by excluding gain on inherited property, see I.R.C. § ror4 (1988), or deferring income through "accelerated" depreciation, see id. § I68 (r988 \& Supp. V 1993). The federal income tax rules may also overstate income from capital, for example, by failing to adjust asset basis for inflation. See generally William D. Andrews, A Consumption-Type or Cash Flow Personal Income Tax, 87 HARV. L. REV. III3, III5 (I974) (arguing that the federal income tax system's “worst inequity, distortion, and complexity arise out of inconsistency in the treatment of accumulation").

145 The federal estate and gift tax is a tax on wealth that applies only to the richest households and only at the time of transfer. See I.R.C. $\$ \$ 2001-2663$ (I988 \& Supp. V I993).

146 The EITC's earnings subsidy is based on "earned income," but the EITC's income test reduces benefits based on the greater of earned income or adjusted gross income (AGI). AGI includes all taxable sources of income, and earned income includes taxable and nontaxable compensation for services. See id. $\$ \$ 32$ (c)(2), 62 (Supp. V I993); Treas. Reg. $\$$ I.32-2(c)(2) (as amended (992). 
legally, for EITC benefits, which they would not receive if the Code measured income (and wealth) more accurately. ${ }^{147}$

In contrast, traditional income-transfer programs tailored to need make relatively comprehensive assessments of income and wealth. Most programs attempt to measure all sources of cash available to meet the living expenses of a family, with limited deductions for expenses. ${ }^{148}$ The programs typically consider the value of assets as well as income to assess accurately the need for benefits. ${ }^{149}$

Recent scholarship has paid little attention to the issue of income definition for the EITC. ${ }^{150}$ In contrast, economists and legal scholars

147 See infra p. 575-76. The issue is not that poor people are understating their incomes by claiming accelerated depreciation or shifting assets into municipal bonds. Truly poor people do not have assets of that kind. The issue is that non-poor people may "look" poorer than they are on the basis of their income reported for tax purposes. See Cherie J. O'Neil \& Linda B. Nelsestuen, The Earned Income Credit: The Need For a Wealth Restriction for Eligibility Determination, 63 TAX Notes I I89, I I99-200 (1994) (describing one EITC recipient who received taxexempt interest income of $\$ 187,000$ ). In addition, the exclusion of some items, like imputed rent and transfer payments, may weaken the federal income tax system's ability to draw distinctions among the poor.

148 AFDC, for example, generally counts most cash receipts, including gifts and child support in excess of certain nominal amounts, as income. The income and resources rules are complex and may vary from state to state. See 42 U.S.C. $\S 602$ (I988); 45 C.F.R. $\$ 233.20$ (I993). For a description of AFDC income rules, see Adele M. Blong \& Timothy J. Casey, AFDC Program Rules for Advocates: An Overview, 25 Clearinghouse Rev. 874, 88I-84 (1991); and 1994 GreEN Book, cited above in note 2, at 327-30. For SSI and Food Stamp income rules, see 42 U.S.C. $\S$ I382a (I988); and 7 U.S.C. § 2014 (I 988), respectively. For descriptions of these rules, see 1994 GREEN BOOK, cited above in note 2 , at $21_{3}-14,763-65$. Welfare programs' income definitions are not necessarily more comprehensive in all respects than the income tax rules. For example, the welfare rules generally look to cash receipts rather than to economic accrual of income and so are less sophisticated and comprehensive in their treatment of, among other things, original issue discount. Cf. I.R.C. $\$$ I 272 (a) (1988) (requiring current inclusion in income of original issue discount). In general, however, the welfare rules are better targeted to measuring cash resources available for current consumption, particularly among low-income families. Welfare programs' eligibility rules have been criticized as so complex that, when misunderstood, they may result in denial of benefits to eligible claimants. See BANE \& Ellwood, supra note 1or, at 125-27. My intention is not to exaggerate the accuracy or other virtues of traditional welfare administration, but to point out that, in a tax-based program, there are potentially significant inaccuracies even if administrators and benefit recipients strictly follow the rules. Issues of administrative error and non-compliance - in the EITC and welfare - are analytically distinct.

149 AFDC requires eligible households to have resources of less than $\$ 1,000$. See 42 U.S.C. $\$ 602$ (a)(7)(B) (I 988); 45 C.F.R. $\$ 233.20(a)(3)$ (1993). "Resources" under AFDC include most assets, with exclusions for certain homes, some personal items like clothes and furniture, and up to $\$ 1,500$ for one car. See 42 U.S.C. $\$ 602(a)(7)$ (1988); 45 C.F.R. $\$ 233.20(a)(3)$ (1993). The Food Stamp program resource limit is $\$ 2000(\$ 3,000$ for households with an elderly member), with exclusions for certain cars and homes. See 7 U.S.C. § 2014 (g) (Supp. V. 1993); 7 C.F.R. § 273.8 (1994). Although these rules exclude some potentially valuable assets, even a limited asset test enhances the accuracy of measurement of need, because assets, like income, can fund the purchase of goods and services.

150 There has been no sustained effort to consider the implications of the narrow federal income tax definition of income for the EITC, although several scholars have mentioned the issue. See Steuerle \& Wilson, supra note 136, at 1054-55; Jonathan B. Forman, Improving the Earned Income Credit: Transition to a Wage Subsidy Credit for the Working Poor, I6 FLA. ST. U. L. 
who studied the negative income tax plans of the I960s and I970s unanimously advocated a comprehensive income definition for purposes of the negative income tax, with the goal of coming as close to economic income as possible. ${ }^{151}$ James Tobin, for example, argued in I 968 that:

Taxable income as defined for the federal income tax is so poor a definition of need that to use it as the base for negative income tax payments would be a travesty of common sense and good justice. Society does not want to pay benefits to people with low taxable income but with ample resources - wealth, tax-exempt interest, capital gains, pensions, social security stipends, college fellowships, large itemized deductions, gift receipts, and so on. ${ }^{152}$

Tobin's statement emphasizes the inevitability of the trade off: if constrained to use the federal income tax's income definition, the EITC and other tax-based transfers may award benefits inappropriately. The preferred solution of Tobin and others, however, is also problematic, and it illustrates the fundamental dilemma of tax-transfer integration. Adopting an expanded income definition solely for EITC purposes is likely to compromise the benefits of tax-transfer integration. Separate rules would increase the administrative cost and complexity of the program and could reduce the dignitary advantages of uniform procedures. This trade off creates a continuum of possible solutions. At one extreme lies a completely integrated EITC that fully incorporates the tax system's limited definitions; at the other extreme, a separate set of rules and procedures for the EITC could come to resemble a "mini-welfare program" run by the IRS.

In the middle are numerous possible compromises between integration and separation. For example, the Code might adopt a slightly broader definition of income to be used in tax provisions, like the

Rev. 41, 84, 87-89 (1988); see also The President's 1978 Tax Reduction and Reform Proposals, Hearings Before the U.S. House of Representatives Comm. on Ways and Means, Part 6, 95 th Cong., 2d Sess. 3568 (1978) (paper of Sheldon Danziger \& Jonathan R. Kesselman) (arguing that the adoption of refundable tax credits heightens the need for expanded tax reform); Jonathan $R$. Kesselman, Income Security via the Tax System: Canadian and American Reforms, in CANADAU.S. TAX Comparisons 97, 128-29 (John B. Shoven \& John Whalley eds., r 992) (analyzing arguments for a broader income definition for tax-based transfers).

151 See Green, supra note 6, at 82-99, 165-66; Heineman Comm'n Proposal, Report of the President's Comm'n on Income Maintenance Programs, reprinted in POVERTY POLICY: A CoMPendium of Cash Transfer Proposals, 183, 197-99 (Theodore R. Marmor ed., 1971); Klein, supra note 130 , at 459-87; Popkin, supra note 130 , at 388, 389-403; Tobin, Pechman \& Mieszkowski, supra note 130 , at $1 \mathrm{I}-14$.

152 James Tobin, Raising the Incomes of the Poor, in AGENDA FOR THE NATION II 3 (Kermit Gordon ed., I 968) (footnote omitted). Although the federal income tax base is probably more comprehensive now than in 1968, thanks in large part to the Tax Reform Act of 1986, Pub. L. No. 99-5 I 4, r 986 U.S.C.C.A.N (roo Stat.) 2085-96r, all of the items Tobin mentions remain eligible for some degree of preferential treatment. 
EITC, that require more accurate income measurement. ${ }^{153}$ Such a definition might, for instance, include tax-exempt interest income or disallow business losses in determining total earnings. ${ }^{154}$ The EITC's "earned income" definition illustrates, however, that even a relatively modest change may compromise tax-transfer integration. This definition, which includes some non-taxable items, is a relatively small departure from the normal income tax rules. Nevertheless, critics have charged that the deviation from standard tax rules creates administrative uncertainty for both the IRS and for EITC recipients and may encourage noncompliance. ${ }^{155}$

Major reforms of the federal income tax could reconcile tax-transfer integration with more accurate income measurement, but such changes pose a formidable political challenge. The Tax Reform Act of I $986^{156}$ probably illustrates the outer boundaries of feasible expansions of the federal income tax base. ${ }^{157}$ Further, administrative as well as political considerations effectively limit reform. Without dramatic (and expensive) changes in the tax system's institutional structure or in information reporting requirements for the private sector, the federal income tax system cannot comprehensively measure income.

If the conflict between accurate income redistribution and taxtransfer integration in the EITC were unimportant in practical terms, we might well ignore it. If, for example, only a small portion of the program's total cost were attributable to mismeasurement of need, we might be unconcerned. Alternatively, even if the dollar "leakage" were

153 See, e.g., Forman, supra note 150 , at 83-84. Such a definition might be useful not only for the EITC, but also, for example, for purposes of the income tests that determine the taxability of Social Security benefits, the amount of the dependent care tax credit, and similar provisions.

154 See O'Neil \& Nelsestuen, supra note 147 , at 1200.

155 The earned income definition has been criticized as promoting fraud in the EITC program, and some analysts have proposed returning to pre-1978 law. See Yin, Scholz, Forman \& Mazur, supra note $\mathrm{I} 3 \mathrm{I}$, at $267-68$. An alternative is to take steps to enhance the administrability of the earned income definition. See, e.g., S. 2224 , I03d Cong., 2d Sess. \$ 909, reprinted in I40 CoNG. REC. S7318 (daily ed. June 2I, I994) (requiring the Department of Defense to report nontaxable amounts of earned income to the IRS and to employees). Another example is the expanded income definition that Minnesota uses for purposes of its low-income credits: although the income measure includes AFDC receipts and other nontaxable income, analysts note the difficulty of verifying these amounts. See Paul Wilson \& Robert Cline, State Welfare Reform: Integrating Tax Credits and Income Transfers, 47 NAT'L TAX J. 655, 673.

156 Pub. L. No. 99-5 I4, I986 U.S.C.C.A.N (100 Stat.) 2085-96 I.

157 See generally Joseph A. Pechman, TAx Reform, The Rich and the Poor 86-88 (i989) (describing changes made in 1986). It is possible but seems unlikely that the existence of a larger EITC program could encourage measures to expand the federal tax base or could constrain further erosion of the tax base by raising the cost of tax preferences. Although the EITC is large for a transfer program, its roughly $\$ 26$ billion annual cost is small relative to the size of the income tax system as a whole and is not even particularly large for a tax expenditure. Cf. 1994 GREEN BooK, supra note 2, at 677-79 (noting that, in 1994, the individual federal income tax raised approximately $\$ 540$ billion and that approximate tax expenditures for fiscal year 1995 include $\$ 46$ billion for the home mortgage interest deduction and $\$ 54$ billion for the exclusion for employerprovided health insurance). 
significant in size, we might still be unconcerned if the beneficiaries were either EITC-eligible families who simply receive too large a credit or EITC-ineligible families with incomes only slightly over the EITC income cutoff.

Available data suggest that the problem of income mismeasurement is not large but not insignificant. For I 994 , a Joint Committee on Taxation (JCT) distributional table based on an expanded definition of income (JCT expanded income) indicates that some families with JCT expanded incomes of as much as $\$ 50,000$ to $\$ 75,000$ per year receive the EITC.158 Further, although a precise calculation using published data is impossible, a rough but reasonable calculation suggests that the percentage of total EITC benefits paid to recipients with JCT expanded income in excess of the program's statutory income cutoff is between three and six percent - a small but non-trivial figure. ${ }^{159}$ The three percent figure represents families with incomes of $\$ 30,000$ or more (that is, more than $\$ 4500$ over the 1994 income cutoff). These data do not indicate the magnitude of "overpayments" among EITCeligible families.

Preliminary evidence also suggests that the absence of an EITC wealth test may have a significant effect. A study based on I 988 IRS data shows that up to ten percent of EITC benefits in that year were paid to taxpayers who apparently held investment assets in significant amounts. ${ }^{160}$ Extrapolating from this data, the authors conclude that restricting EITC eligibility based on a modified wealth test could have

158 See 1994 GreEN Book, supra note 2, at 703 tbl. (indicating that about 23,000 families in that income range received about $\$ 20$ million in EITC benefits). The income cutoff for 1994 is $\$ 25,300$ because the 1993 legislative changes will not be fully phased in until 1996 . See id. at 700 ; see also id. at 676 (describing the Joint Committee's expanded definition of income). The only reason for the benefits paid to higher-income families is the inadequacy of the EITC income definition; the tables do not incorporate overpayments due to noncompliance. Personal Communication from Mark J. Mazur, economist (June I5, I993).

159 Because the table is divided into income classes at $\$ 10,000$ increments, it provides only an aggregate figure for EITC benefits paid to families in the $\$ 20,000$ to $\$ 30,000$ range and does not indicate what portion of those payments are made to families with expanded incomes in excess of the 1994 EITC income cutoff of $\$ 25,300$. The low percentage $(2.73 \%)$ cited in the text reflects EITC payments to families with expanded incomes of $\$ 30,000$ or more ( $\$ 537$ million out of total EITC benefits of $\$ 19,647$ million). The high percentage $(5.94 \%)$ cited in the text is based on an arbitrary guess that $15 \%$ of payments in the $\$ 20,000$ to $\$ 30,000$ expanded income range are made to those with expanded incomes that exceed the EITC income cutoff level (for a total of \$II66 million out of total EITC benefits of $\$ 19,647$ million). See id. at 703 tbl.

160 See O'Neil \& Nelsestuen, supra note 147 , at IIgo. The authors use total investment income (taxable and non-taxable), as reported on the tax return, as a proxy for wealth. In I 988 , 10\% of EITC benefits were paid to taxpayers reporting investment income of $\$ 300$ or more. See id. This study probably understates the problem, because it takes into account only incomeproducing investment assets. Other limitations of the methodology exist as well. See id. at I 200-OI. 
reduced the revenue cost of the I993 EITC expansion by five percent. ${ }^{161}$

The problem of income measurement may grow as the EITC program grows. For example, the 1993 expansion of the EITC increased the income cutoff to $\$ 27,000$. Including these relatively well-off families in the EITC population may increase the number of EITC recipients with excludable forms of income. ${ }^{162}$ Further, the political impact of "scandals" involving overpayments to high-income households may be disproportionate to their financial magnitude. One can imagine a politician hostile to the EITC trumpeting that "welfare" benefits are being paid to families making $\$ 50,000$ or $\$ 100,000$ - even though the size of those payments compared to the program as a whole is tiny. ${ }^{163}$

One final argument deserves mention. Many income-transfer programs, including the EITC, are designed to award some benefits to the nonpoor in order to keep benefit reduction rates low. Why, then, should policymakers be concerned about additional EITC benefits that flow to the nonpoor due to the understatement of economic income? The problem is that the two types of payments to the nonpoor may differ significantly in their political visibility and their distributional effect. Payments that result from extending eligibility for benefits above the poverty line are immediately apparent in the design of the program and are equally available to all who meet the eligibility criteria and fall within the income range. Overpayments related to the income definition, however, tend to be both hidden and arbitrarily distributed, because they are available only to those with tax-favored sources of income.

2. Defining the "Family." - The definition of "family" creates similar institutional dilemmas. The federal income tax rules adopt a

161 The authors acknowledge the difficulty of measuring wealth directly. The five percent figure is based on disallowing the EITC to taxpayers reporting investment income of more than $\$ 1200$ per year. See id. at 1200.

162 The Joint Committee on Taxation's distributional table for I996 shows that at least six percent of EITC benefits will be paid to families with expanded incomes greater than the EITC income cutoff, then $\$ 28,524$. See 1994 GREen Book, supra note 2, at 703 (reporting that $5.81 \%$ of EITC benefits will be paid to families with expanded incomes greater than $\$ 30,000$ ). The actual number is probably higher, because some families shown in the $\$ 20,000$ to $\$ 30,000$ income range in the JCT table presumably have incomes that exceed $\$ 28,524$.

163 The prototypical "horror story" is likely to be a wealthy person whose wealth is invested in tax-exempt bonds or other tax-preferred assets. She might work short hours even at a relatively high wage and still qualify for EITC benefits.

The EITC could be particularly vulnerable to these attacks, because overpayments due to income mismeasurement occur even when the rules are being followed, in contrast to the typical "welfare queen" stories about noncompliance. See, e.g., Seth Faison, Officials Say Woman on Welfare Stole Thousands With Fake ID's, N.Y. Times, May 20, I994, at BI; Woman's Aid Claims for 38 Children Are Examined, N.Y. TIMEs, Dec. $2 \mathrm{I}$, 1980, at $3 \mathrm{I}$; see also Evelyn Z. BrodKIN, The False Promise of Administrative Reform: Implementing Quality Control in WelFARE 24-40 (I 986 ) (describing the "transition from a prevailing concern with poverty's causes and cures to an overriding concern with welfare's costs and mismanagement"). 
narrow definition of the family. Although current federal income tax law nominally treats the family rather than the individual as the taxable unit, the "family" for this purpose is best understood as the married couple. Most husbands and wives have little reason to file separate returns. Unmarried individuals must file separate returns regardless of shared living or support arrangements. ${ }^{164}$ A taxpayer may claim personal exemptions for children and other dependents, ${ }^{165}$ but the income of children and other dependents generally is not reported on the taxpayer's tax return. ${ }^{166}$ In contrast, income-transfer programs typically adopt a broader definition of family that includes most relatives who live together. ${ }^{167}$

The EITC follows the federal income tax in treating the married couple as the basic family unit and in disregarding the income of other household members. For purposes of determining benefits - but not measuring income - the EITC takes into account a taxpayer's relationship to a child based on rules that differ somewhat from the "dependency" definition used for regular tax purposes. ${ }^{168}$ Although the new rules adopted in 1990 were intended to improve accuracy and compliance, they have come under attack for their complexity and potential adverse effects on participation - and illustrate again the ten-

164 See I.R.C. $\$$ I(a), (d) (Supp. V I 993). The rate schedules and other rules are designed so that there is rarely any advantage to separate filing by married couples. See id. (providing that tax rate brackets for married individuals who file separately are half as wide as for married couples who file jointly). Other provisions also help ensure that most married taxpayers will get no benefit from filing separately. See, e.g., id. $\$ 63$ (c)(6)(A) (I988) (denying the standard deduction to married persons who file separately if either spouse itemizes deductions); id. § 68(b)(I) (Supp. V I993) (providing that the phase-out of itemized deductions begins for a married person filing separately at half the income level for married couples filing jointly).

165 See id. \$ I5 I (Supp. V I 993). Dependency is established using a multi-factor test, including support, relationship, age, gross income, and citizenship. See id. $\$ 152$ (1988). Single individuals who "maintain[ ] a household" for children or certain dependents, id. § 2(b) (I 988), are eligible for "head of household" filing status, which confers an advantageous tax rate schedule and certain other advantages. Id. § I(b) (Supp. V I993).

166 Unearned income of minor children that exceeds a threshold is taxed at the parent's marginal tax rate, and parents can elect, in some cases, to report the child's income on their return. See id. \$ I (g) (Supp. V I993).

167 Very generally, under AFDC, the family unit includes the parents of a dependent child and any dependent full- or half-siblings living in the home. See 42 U.S.C. $\$ 602$ (a)(7)(A), (a)(38) (I988 \& Supp. V I 993); 45 C.F.R. \$ 206.IO(a)(I)(vii) (I993); Blong \& Casey, supra note I48, at 88I-82. SSI aggregates only the incomes of married couples and provides certain adjustments to take account of support provided by other household members. See 42 U.S.C. \$ I382a (I988); 1994 Green BooK, supra note 2, at 217-18. The Food Stamp program uses a comprehensive definition of "family" that generally includes all members of a household who purchase food and prepare meals together. See 7 U.S.C. § 2012 (i) (Supp. V r993); OHLS \& BEEBout, supra note 64, at 22-25.

168 Compare I.R.C. $\$ 32$ (c)(3) (Supp. V. I 993) (defining "qualifying child" for purposes of determining EITC eligibility) with I.R.C. § $5_{52}$ (a) (I988) (defining "dependent"). 
sion between tax-transfer integration and reforms to improve the EITC's performance. ${ }^{169}$

Whether the EITC's rather narrow family definition distorts the desired pattern of income redistribution to any significant degree is an empirical question. Unfortunately, no publicly available data shed light on the magnitude of the problem. ${ }^{170}$ In principle, however, the failure to define family in a realistic way is as troubling as the exclusion of certain sources of income. Careful program design might mitigate but cannot eliminate the potential inaccuracy. ${ }^{171}$ For example, the EITC pays the largest benefits to working families with children and provides benefits for childless workers only between the ages of twenty-five and sixty-five. ${ }^{172}$ These rules tend to improve accurate targeting in a rough way, by excluding elderly people and teenagers two groups who are particularly likely to live in households in which they receive support from others.

Adopting truly precise family definition rules for purposes of the EITC would, even if desirable, be administratively difficult. Presumptions of financial support and of shared expenses within a household are difficult to formulate and to defend. ${ }^{173}$ Although the federal in-

169 For criticism of the new rules, see Part IV.D below. The problems that prompted the adoption of special EITC rules in 1990 illustrate how family definitions that function reasonably well as applied to many taxpayers may prove inadequate for a tax-based transfer program. Before I990, IRS compliance studies showed that a large percentage of EITC recipients were in fact ineligible for the EITC, and overpayments were associated with errors in filing status or dependency claims. See Holtzblatt, supra note I3 I, at I83. Low-income families often receive a significant percentage of their income in the form of transfer payments. See 1994 GrEen BoOK, supra note 2, at II44-47. Although such payments are not taxable, they can defeat a "dependency" or "household maintenance" determination, and result under pre-I 990 law in denial of the EITC. See Yin, Scholz, Forman \& Mazur, supra note I3I, at $27 \mathrm{I}$.

170 The JCT distribution tables use the tax filing unit as the "family" unit and so generally do not capture the extent to which the EITC overpays benefits due to the narrow family definition. See StafF of The Joint Comm. ON TAXation, supra note 29, at 97.

171 The EITC adopts additional eligibility rules to minimize awards of the EITC based on inadequate family definitions; these rules do not necessarily increase the theoretical accuracy of the EITC's family unit rules, but they do minimize revenue loss. For example, an adult single parent who earns low wages but lives with her middle-class parents would be ineligible for the EITC under the Code. See I.R.C. $\$ 32$ (c)(I)(C) (Supp. V I993). Under that rule, because her child would be a "qualifying child" for her parents too, her parents' higher AGI would preclude her from claiming the EITC. Id. $\$ 32$ (c)(I)(C) (Supp. V I 993 ).

In theory, an alternative to expanding the definition of "family" for income measurement purposes is to require all individuals or married couples to include in their income the support they receive from others, but such a proposal would require a major change in federal income tax law and would raise issues of administrability. Scholars of the negative income tax typically recommended both expanding in some way the definition of the family and including at least some support payments in income. See, e.g., Klein, supra note 130 , at 459-63; Popkin, supra note $\mathrm{I}_{30}$, at 392-95, 403-09; Tobin, Pechman \& Mieszkowski, supra note 130, at 9-1 I, I3-14.

172 See I.R.C. $\$ 32$ (b), (c)(I)(A) (Supp. V I 993).

173 For example, not all married couples share expenses and pool resources, even if they live together. See Gann, supra note 108, at 26 \& n.97; Munnell, supra note 121 , at 266 . The situation of unmarried people living together is even more complicated because cohabitation outside mar- 
come tax system as a whole may eventually have to adapt to the realities of changing American family structures, virtually no one now advocates or anticipates the expansion of the tax system's family definition. ${ }^{174}$ Once again, then, the goal of tax-transfer integration constrains both the current effectiveness of the EITC and efforts to improve its performance.

\section{The Conflict Between Tax-Transfer Integration and Responsiveness to Changing Circumstances}

Because incomes fluctuate - sometimes dramatically - as jobs are won and lost, wages and hours worked change, and marriages form and dissolve, the measurement interval is important. The length of the accounting period affects the aggregate amount of taxes collected or transfers paid in any system in which marginal tax rates vary. ${ }^{175}$ Under the regressive marginal tax rate structure characteristic of the EITC and other income-tested transfer programs, ${ }^{176}$ shorter accounting periods tend to favor those with fluctuating incomes: their benefits are likely to be higher, in the aggregate, than those of individuals with steady incomes. ${ }^{177}$ Under the federal income tax, in contrast,

riage comprises a wide variety of relationships, and distinguishing arrangements in which support is present from those in which support is absent is likely to prove impossible without individualized determination of a kind that current tax procedures cannot accommodate. See Klein, supra note 108 , at $40 \mathrm{I}$ (concluding that "no set of rules will be perfectly adapted to all conceivable circumstances").

174 In fact, proposals for reform in the last 15 years have typically advocated filing by each individual, without regard to marital status. See, e.g., Harvey E. Brazer, Income Tax Treatment of the Family, in THE Economics OF TAXATION, supra note I2I, at 223, 238-45; Gann, supra note 108, at 67-69; Julie A. Nelson, Tax Reform and Feminist Theory in the United States: Incorporating Human Connection, I8 J. ECON. STUD. II, I8-27 (1991); June O'Neill, Family Issues in Taxation, in TaXing the Family I, I8-I9 (Rudolph G. Penner ed., I983).

175 Fluctuating incomes would not affect taxation in a system with a constant marginal tax rate. See Kesselman, supra note III, at 228. For an excellent discussion of the issues posed by fluctuating incomes in income-transfer programs, see Asimow \& Klein, cited above in note 130 , at 6-I0.

176 See supra note rog and accompanying text (demonstrating the EITC's regressive marginal tax rates). See generally Kesselman, supra note II I, at $221-26$ (describing accounting problems in a negative income tax). The EITC creates a regressive marginal rate structure for incomes that fluctuate between the phase-out range and the range of incomes above the income cutoff line. Consequently, the EITC tends to award greater benefits to those with incomes that fluctuate between these ranges. An EITC recipient whose earnings fluctuate within the phase-in range or within the phase-out range will find that benefits are neither understated nor overstated, because the marginal tax rate (the earnings subsidy rate or phase-out) is constant. A worker whose earnings fluctuate between the phase-in and phase-out ranges may be overpaid or underpaid.

177 For example, suppose there are two periods (one and two), and the taxpayer earns $\$ 10$ in period one and $\$ 25$ in period two. A hypothetical transfer program provides a maximum benefit of five dollars, a benefit reduction rate of $33 \%$, and an income cutoff of $\$ 15$. Incomes greater than $\$ 15$ but no greater than $\$ 30$ are subject to income tax at a marginal tax rate of $10 \%$. If income is measured (and benefits are awarded) for each period, the taxpayer will receive a benefit of $\$ 1.70$ in period one. She will receive no transfer benefits in period two and will owe positive income tax of one dollar. Her net transfer for the two periods would be $\$ 0.70$. In contrast, a 
marginal tax rates rise with income and produce a progressive marginal income tax rate structure, which tends to impose higher total tax burdens on those with fluctuating incomes than on those with steady incomes.

Ideally, a tax or transfer system would both respond quickly to changing circumstances and react only to real changes in economic well-being. ${ }^{178}$ In practice, however, the two goals conflict. Responsiveness implies immediate adjustment to short-term changes, but accurate income measurement implies waiting to evaluate the permanency of the change in circumstances. Longer accounting intervals, as in the federal income tax, more accurately evaluate the permanency of change and thus tend to reduce the impact of fluctuating incomes. ${ }^{179}$ Traditional income-transfer programs, in contrast, typically measure income at much shorter intervals, usually monthly, in order to maximize responsiveness to changing circumstances. ${ }^{180}$

The EITC, as a tax-based program, is thus inherently unresponsive relative to traditional transfer programs. Is this unresponsiveness a problem? One might argue that a degree of sluggishness in traditional income transfers could be beneficial, because it encourages work effort. Delays in awarding traditional benefits may discourage voluntary decisions to leave employment, and delays in eliminating benefits may reward initial efforts to find and hold a job. ${ }^{181}$ Unresponsiveness may impose real hardship on those for whom unemployment is involuntary, however, and may expend scarce resources on those who are no longer needy. In addition, unresponsiveness in the EITC, in contrast to traditional transfer programs, could, in some cases, discourage work by delaying transmittal of the EITC's earnings subsidy. ${ }^{182}$ The prob-

taxpayer with steady income ( $\$ 17.50$ in each period) would receive no benefits and would pay income tax of $\$ 0.25$ in each period, for a net tax of $\$ 0.50$. If income were measured (and benefits were awarded) only at the end of period two (and the income cutoff, income tax threshold, and maximum benefit levels were doubled), both individuals would report income of $\$ 35$, neither would receive benefits, and each would owe total income tax of $\$ 0.50$.

178 This section addresses "responsiveness" in only the rather narrow sense of temporal responsiveness, that is, how quickly benefits are awarded or taken away if the program functions according to its legal terms.

179 Although the federal income tax system adopts an annual accounting period, it requires payment at more frequent intervals in order to ensure current payment of a high percentage of the year's tax. See I.R.C. $\$ \S 3402,6654,6655$ (I988 \& Supp. V 1993). Unfortunately, the relative accuracy of the federal income tax system's rules in measuring income over time does not offset the inaccuracy of its definitions of income and family. The federal income tax simply does a relatively accurate job of measuring income as inaccurately defined.

180 Welfare programs typically require monthly reporting for at least some recipients (often those with earnings or a work history, because their income is more likely to fluctuate). See 7

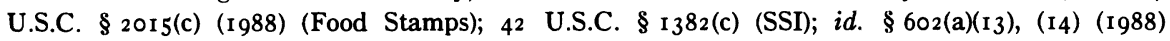
(AFDC).

181 See Asimow \& Klein, supra note 130 , at 10.

182 In theory, the EITC's unresponsiveness would not affect its incentives if people anticipate receipt of the EITC and understand the link between work effort and the receipt of the EITC. 
lem appears increasingly serious as the income support function of the credit expands and the EITC grows from several hundred to several thousand dollars a year. ${ }^{183}$

Congress attempted in 1978 to enhance the responsiveness of the EITC by enacting the "advance payment" rules, which permit periodic payment of the EITC by employers throughout the year. ${ }^{184}$ Recipients of advance payments must file a tax return at the end of the year. If advance payments received exceed the EITC computed at year end, the recipient must repay the excess to the government. ${ }^{185}$ Available data indicate that the advance payment option is rarely used. A 1992 General Accounting Office study shows that fewer than one-half of one percent of EITC recipients chose the advance payment option in I $989 .{ }^{186}$ Although the advance payment system is plagued by numerous administrative problems, ${ }^{187}$ one central reason that EITC recipients avoid advance payments is that they quite rationally fear a yearend tax liability due to overpayment of benefits during the year. ${ }^{188}$

Some analysts, however, have expressed concern that receiving the EITC in a lump sum at the year's end, rather than more frequently throughout the year, obscures the connection between the EITC and work. See, e.g., S. REP. No. 1263 , 95th Cong., $2 \mathrm{~d}$ Sess. 52 (1978), reprinted in 1978 U.S.C.C.A.N. 6761, 6815; Olson with DAvis, supra note 55, at 9-13.

Some defenders of the EITC argue that annual receipt of the EITC enables poor families (like many middle-class ones) to opt voluntarily for forced savings by deferring receipt of a refund or EITC payment until the annual date. See Shapiro \& Greenstein, supra note 8, at 26 . Seventyfive percent of all taxpayers typically receive tax refunds due to overwithholding. See U.S. GENeral Accounting Office, Earned Income Tax Credit: Advance Payment Option is Not Widely KNOWN OR UNDerstood By the Public i6 (GAO/GGD-92-26, Feb. I 992) [hereinafter GaO Advance Payment Report]. There is evidence that some EITC recipients prefer annual payment. See id. at 3 ; OLSON WITH DAvis, supra note 55 at 10-1 I. Nevertheless, the unresponsiveness of the EITC continues to draw criticism.

183 See Shapiro \& GREenstein, supra note 8, at 26-28.

184 See Revenue Act of 1978 , Pub. L. No. 95-600, $\$$ ro5(b)(r), 92 Stat. 2763, 2773-76 (codified at 26 U.S.C. $\$ 3507$ ( 1988$)$ ). Under the advance payment rules, a worker who certifies to her employer that she expects to be eligible for the EITC receives installment payments of the credit each pay period, with each installment based on earnings for the pay period. See I.R.C. §3507 (1988 \& Supp. V 1993). These rules in effect assume that each pay period's earnings accurately reflect a pro rata portion of total income for the year.

185 See I.R.C. $\$ 32(\mathrm{~g})(\mathrm{I} 988)$. Conversely, the taxpayer receives an additional credit if advance payments fall short of the EITC as calculated on the return. See id.

186 See GAO Advance PAyment Report, supra note 182 , at 3.

187 The GAO found that many EITC recipients and their employers were unaware of the advance payment option and that there was widespread confusion and noncompliance when advance payments were made. See id.

$188 \mathrm{See}$ id. at $\mathrm{r}_{4}$. In fact, even people involved in EITC outreach are reluctant to promote the advance payment option: the IRS is concerned about noncompliance, tax preparers prefer to maximize year-end refunds, and social workers worry about taxpayers' owing the IRS money at the end of the year. See Stephen D. Holt, Improvement of the Advance Payment Option of the Earned Income Credit, 57 TAX NoTES ${ }_{583}$, 1584 n.8 (1992). For families with stable low incomes, the absence of a workable advance payment feature may be "only" a first-year problem, because the EITC received at the end of the first year can be spent all through the second year, and so on. This view assumes, however, that families can rationally budget to use a lump sum 
In recent years, the EITC's lack of responsiveness has generated a variety of proposals for reform. Some commentators propose programs to improve awareness of and employer participation in the advance payment program; others propose to curtail or to eliminate the advance payment option. ${ }^{189}$ What these critics have typically missed, however, is that real improvement in the responsiveness of the EITC is possible only at the cost of tax-transfer integration or of costly transformation of existing tax institutions.

The basic problem is that the advance payment system (even if successfully implemented) cannot avoid the underlying institutional dilemma. Advance payment creates the illusion of responsiveness, but it cannot deliver true responsiveness as long as the EITC remains linked to the annual accounting interval of the federal income tax. The fear of EITC recipients that the advance payment system will leave them owing money to the government at the end of the year is wellfounded. The short accounting intervals of the advance payment system tend to "overpay" benefits during the year to those with fluctuating incomes, and reconciliation at year end requires recipients to repay the "excess" benefits they received. ${ }^{190}$ Attempting to recapture such overpayments may inflict hardship on the families involved. Even if absolute amounts are small, they may be large in relative terms for poor families. Collecting small amounts from relatively poor people may also impose disproportionately high collection costs on the Inter-

throughout the year and ignores the rules that treat EITC refunds as "resources" for purposes of determining eligibility for means-tested programs such as AFDC and Food Stamps if not spent quickly. See supra note 40.

189 See Staff of House Comm. on Ways \& Means, 103d Cong., 1st Sess., Fiscal Year 1994 Budget Reconciliation Recommendations of THE CoMm. ON Ways and MEANS 172 (Comm. Print 1993); GAO Advance PAyment Report, supra note 182, at 5 (recommending that the IRS take additional steps to increase awareness of the advance payment option); Holt, supra note 188, at 1586-87; Yin, Scholz, Forman \& Mazur, supra note 131, at 266, 274-78.

190 The analysis of the problem of recapturing EITC overpayments applies to EITC recipients with incomes that fluctuate between the EITC phase-out range and the range of incomes above the income cutoff. It is over this range that the combination of the EITC and the regular tax system creates regressive marginal tax rates. EITC recipients with incomes (or earnings) that fluctuate between other ranges may receive over- or underpayments. See supra note 176.

This structural recapture problem does not occur in the income tax system. The federal income tax, like the EITC advance payment system, incorporates a disjunction between payment periods and accounting periods by collecting tax at frequent intervals but determining final tax liability measured on an annual basis. Because the positive income tax system has progressive marginal tax rates, however, fluctuating incomes tend to result in overpayments rather than underpayments of tax. Although underpayments requiring recapture certainly occur, they do not typically result solely from fluctuating incomes.

The problem of recapture also is absent in traditional welfare programs, but for a different reason. AFDC, SSI, and Food Stamps use a short accounting period with no recapture. Thus, although "overpayments" measured on an annual basis inevitably occur, the rules of the programs do not typically measure them or require repayment. 
nal Revenue Service: given the small "stakes" in any individual case, the cost of IRS collection efforts may exceed the potential return. ${ }^{191}$

Only structural change would enhance the EITC's responsiveness. The EITC could adopt a shorter accounting period without year-end reconciliation, which is the approach used in traditional transfer programs. ${ }^{192}$ This solution would require a separate set of rules that is likely to compromise tax-transfer integration, however, because the tax system itself continues to operate on an annual basis. ${ }^{193}$ Another way of alleviating the problem would be to change the system of tax withholding. A "cumulative" system of withholding, like the system used in the United Kingdom, would automatically adjust for fluctuating incomes of EITC recipients and regular taxpayers alike. ${ }^{194}$ The complexity of such a system makes it unlikely that employers would realistically adopt it solely for EITC purposes, however, and conversion of the U.S. income tax withholding system to a cumulative system would be costly. Such a massive disruption of the federal income tax system is unlikely to be undertaken solely to improve the EITC,

191 For example, the General Accounting Office found that the IRS cannot detect noncompliance in time to prevent claimants from receiving the EITC both in advance and with the tax return, and once the IRS does detect noncompliance, the General Accounting Office says that the IRS is "unlikely" to recover much money. See GAO AdVANCE PAYMENT RePORT, supra note I82, at 24,28 . Two-earner couples and workers with non-wage income also are likely to receive overpayments. See the examples in Holt, cited above in note 188 , at $1585-86$.

192 See Yin, Scholz, Forman \& Mazur, supra note I3I, at 276-77.

193 Cf. Kesselman, supra note I50, at I29-33, I43 ("In concept, this deficiency [in the responsiveness of tax provisions] could be remedied through frequent periodic income reporting by beneficiaries and corresponding adjustment of their benefits. But this would entail major administrative resources and would not be easily accommodated within the personal tax system."). The federal tax law requires individual and corporate taxpayers to make quarterly estimated tax payments. See supra note I79. These quarterly returns, however, do not provide a ready vehicle for shorter EITC accounting periods because they operate only to require prepayment of tax that is determined finally on the annual tax return.

194 The present withholding system treats the current period's pay as if it accurately represents a pro rata portion of the employee's total earnings for the year. In contrast, in a cumulative withholding system, like the United Kingdom's "pay-as-you-earn" (PAYE) system, employers track employees' cumulative earnings and adjust withholding in each period to reflect changing circumstances. See Kesselman, supra note I I I, at 226-27; cf. James E. Williamson \& Francine J. Lipman, The New Earned Income Tax Credit: Too Complex For the Targeted Taxpayers?, 57 TAx NoTES 789, 802-03 (I992) (advocating adoption of a PAYE system for single employees with only wage income). The city of Milwaukee is considering adopting a system, solely for advance payment of the EITC, that would incorporate cumulative earnings data. See Stephen D. Holt, Effect of 1993 Budget Act on the Advance Payment Option of the Earned Income Credit, 62 TAx NoTES 759,763 (1994). Another alternative is to adopt rules that improve on both the federal income tax model and the traditional transfer-program model. For example, Michael Asimow and William Klein have developed, for purposes of the negative income tax experiments, a system that combines monthly retrospective reporting with an averaging mechanism they call the "carryover system." Asimow \& Klein, supra note I30, at ro-3r. Once again, however, abandoning conformity with the federal income tax would raise administrative costs and would likely sacrifice other component goals of tax-transfer integration. 
which, although large as a transfer program, is small in relation to the entire income tax system. ${ }^{195}$

The most recent amendments to the EITC's advance payment system illustrate the intractability of the problem. The I993 amendments limit advance payments for all recipients to sixty percent of the EITC benefit to a family with one child. ${ }^{196}$ This change reduces the potential for overpayments but further restricts the already limited responsiveness of the advance payment system. The reduction in overpayment and later recapture for some families comes at the cost of reduced responsiveness for others, who must forgo current payment of a significant portion of their EITC benefit. ${ }^{197}$

\section{Tax-Transfer Integration and the Trade off Between Compliance and Participation}

Compliance and participation are two important objectives of any tax or transfer program. Compliance is essential because rules for assessing taxes or awarding benefits based on income or other criteria are useless unless those rules are enforced. ${ }^{198}$ Participation is critical because income-transfer programs cannot improve the economic situation of families unless the benefits are claimed. Income tax systems also typically seek maximum participation in order to spread the tax burden fairly among taxpayers. Income-transfer programs encounter a familiar trade off between compliance and participation: efforts to increase compliance can reduce eligible beneficiaries' willingness to come forward and claim the benefits to which they are entitled. ${ }^{199}$

195 The total cost of the EITC in fiscal year I995 is projected to be $\$ 2$ r.6 billion. See 1994 GREEN BOOK, supra note 2, at 678 . In contrast, in I994 the federal income tax raised over \$54 I billion. See id. at 677 .

196 See I.R.C. $\$ 3507$ (b), (c) (West Supp. 1994).

197 The I990 amendments also limited advance payments by excluding from the advance payment system the additional credit amounts for larger families, young children, and purchasers of health insurance. See Omnibus Budget Reconciliation Act of I990, Pub. L. No. I01-508, § IIIII(c), I04 Stat. 1388, I388-4I2 (I990), amended by Omnibus Budget Reconciliation Act of I993, Pub. L. No. 103-66, § I3 I3 I, I07 Stat. 312, 433-35 (I993) (codified at I.R.C. \$ 32 (I988 \& Supp. V 1993)). EITC recipients could in theory obtain private loans against future EITC receipts, but obtaining credit may be difficult, given the borrower's low income and the sensitivity of the EITC to fluctuations in income. Even if private credit were available, the riskiness of the loans would probably dictate a high interest rate, which might provoke public concern. $C f$. Asimow \& Klein, supra note $\mathrm{I} 30$, at 8-9 (explaining that private loans could be expensive and difficult to obtain and that substituting a government credit program "would, after all, be just one more needs-tested program of a sort"). Commercial tax preparers' "'refund anticipation' loans" are available only after the annual return is filed. See Jan M. Rosen, Electronic Filing For Tax Returns, N.Y. TIMES, Feb. 10, I990, at 34 .

198 Rational policymakers, of course, assume a certain level of noncompliance when designing a program, but compliance efforts remain necessary to contain compliance within anticipated boundaries.

199 For example, efforts to verify information about income, employment, and children can require long and complicated forms and certifications from third parties. In the early ig8os, for 
The EITC encounters a similar trade off. It seems likely to achieve impressive participation rates, because participation in a tax-based program appears easier and more attractive than participation in a traditional welfare program. A tax-based program requires only the filing of a tax return - recipients need not travel to a welfare office, wait in line, confront brusque or overworked caseworkers, or register for work or training programs. ${ }^{200}$ On the other hand, the poor typically do not have to file tax returns except to claim the EITC. Ironically, the traditional tax policy goal of exempting the poor from income taxation tends to undermine automatic EITC participation. ${ }^{201}$ In response, the IRS and a number of private groups have undertaken community outreach efforts in recent years to spread information about the EITC. ${ }^{202}$

Despite potential information failures, available data confirm that the EITC has relatively high participation rates. A I993 study by John Karl Scholz of the University of Wisconsin found that in 1990 the EITC's participation rate was between eighty and eighty-six percent. $^{203}$ Although Scholz's estimate indicates that in I990 as many as

example, estimates indicate that efforts to crack down on welfare cheating reduced the welfare rolls significantly - in part by turning away eligible applicants who could or would not cope with the complex procedures designed to ensure compliance with eligibility requirements. See, e.g., BRODKIN, supra note 163 , at 44-45; Handler, supra note 18, at 481-82; Michael R. Sosin, Legal Rights and Welfare Change, 1960-1980, in DANZIGER \& WeINBERG, supra note I0I, at 260, 276-77.

However, not all compliance efforts necessarily reduce participation, and numerous factors other than compliance efforts - including, for example, pride or lack of information - may affect participation rates. Commentators have provided demographic, economic, and other explanations for low participation rates in transfer programs. See, e.g., Richard D. Coe, Nonparticipation in Welfare Programs by Eligible Households: The Case of the Food Stamp Program, $27 \mathrm{~J}$. ECON. Issues 1035, I05 I (1983); Thomas P. McDonald \& Irving Piliavin, Failure to Participate in AFDC: Some Correlates and Possible Influences, Soc. Work REs. \& ABstracts, Fall I984, at 17, 22; Philip K. Robins, A Decade of Declining Welfare Participation: Sorting out the Causes, 8 CONTEMP. POL'y Issues IIO, III-I2 (I990).

200 See Yin, Scholz, Forman \& Mazur, supra note I3I, at 252.

201 One of the major goals of the Tax Reform Act of 1986 was the removal of poor taxpayers from the income tax rolls. The 1986 Act increased the personal exemption and standard deduction and indexed them for inflation. See Tax Reform Act of 1986, Pub. L. No. 99-5 I4, $\$ \S$ I02-I03, 100 Stat. 2085, 2099-103 (I986) (codified at I.R.C. \$§ 63(c), I5 I (Ig88)); STAFF OF the Joint Comm. on Taxation, 99th Cong., 1st Sess., General Explanation of the Tax Reform ACt OF 1986 i5 (Comm. Print ig87).

202 For descriptions of recent EITC outreach efforts, consult Adrian Lanzillotti, Service Attempts to Inform Low-Income Taxpayers of EIC Benefits, 33 Highlights \& Documents 2255 (1994); and 1993 Welfare Reform Hearings, cited above in note 29, at I3 (statement of Stephen D. Holt, Acting Director, Congress for a Working America), which describes EITC promotion in Milwaukee.

203 See Scholz, supra note 62, at 65 . Scholz notes, however, that changes in the design of the EITC since 1990 may cause participation rates to vary from his 1990 estimate. See id. at 72 ; see also John K. Scholz, The Participation Rate of the Earned Income Tax Credit i8 (University of Wisconsin-Madison, Inst. for Research on Poverty, Discussion Paper No. 928-90, 1990) (estimating EITC participation rate of $76 \%$ in 1988 ). 
2.I million eligible taxpayers did not claim the credit, ${ }^{204}$ the EITC participation rate is still substantially higher than participation rates in traditional income-transfer programs. ${ }^{205}$

Enforcing compliance with EITC rules is more difficult. The EITC presents two intrinsic problems of compliance and enforcement: the unusual problem of incentives for income overstatement, and the disproportionate cost of collecting erroneous overpayments from EITC recipients. First, existing compliance mechanisms generally attempt to detect or prevent the understatement of earnings, which is the normal compliance problem faced by the IRS. The EITC, however, tends to encourage overstatement of earnings, at least by nonworkers and workers with earnings in the subsidy range. ${ }^{206}$ A poor nonworker with two children, for example, might receive a $\$ 3370$ EITC simply by increasing the earned income she reports to $\$ 8425 .{ }^{207}$ The economist Eugene Steuerle terms the problem of exaggerated earnings the "superterranean economy" and argues that "[b]luntly stated, the IRS cannot enforce the EITC as it is currently designed, much less as it would be expanded in the [I993 legislation]."208

204 See Scholz, supra note 62 , at 65.

205 See id. at 7I; see also 1994 GreEN BooK, supra note 2, at 242 (estimating that, in I992, approximately $52.7 \%$ of the elderly poor received SSI); CAROLE TRIPPE \& PAT Doyle, U.S. Dep't of Agriculture Food Stamp Program Participation Rates: January 1989 at vii (I992) (estimating a 59\% participation rate for eligible individuals and a $56 \%$ participation rate for eligible households).

206 Overstatement of earnings benefits the recipient only up to total earnings of $\$ 8425$, because EITC benefits do not increase as earned income exceeds $\$ 8425$. See supra p. 541 .

207 See supra pp. 54I-42 and accompanying table and graph.

208 Gene Steuerle, The IRS Cannot Control the New Superterranean Economy, 59 TAx NotES I839, I 839 (1993).

Gaps in coordination between the tax and transfer systems may allow an EITC recipient to overstate her earnings in order to maximize her EITC benefit without suffering a reduction in other income-tested transfer benefits. The Code allows the Internal Revenue Service to share limited information with welfare agencies. See I.R.C. $\$ 6$ Io3 $(l)(7)$ (1988). State agencies administering AFDC, Medicaid, and Food Stamps must operate an "income and eligibility verification system" (IEVS), which uses IRS income data to assist in determining eligibility for these benefits. 42 U.S.C. $\$ \S 602(a)(25), 1320 b-7(a)(2)(1988)$. Even if IRS information is inconsistent with income as reported for welfare purposes, however, the agency may not deny benefits automatically, but must instead verify the information independently and provide notice and a hearing to the recipi-

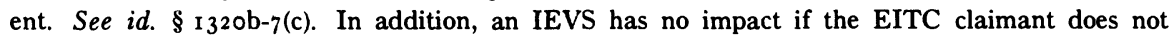
receive public benefits. Eugene Steuerle has argued that taxing transfer payments would be one way to enhance administrative coordination between the federal income tax system and transfer programs. See Gene Steuerle, Has the Time Come to Tax Welfare and Other Transfer Payments?, 63 TAX Notes I 365, I365 (I994).

The EITC also creates the opportunity for more familiar forms of noncompliance. For example, a taxpayer with income in or above the EITC phase-out range could increase her EITC by understating earnings or other income, or by claiming that nonresident children live with her. The IRS's usual methods for detecting noncompliance would address these strategies. Some noncompliance and fraud is relatively easily detected. For example, the IRS's computer matching program detects amounts reported by employers which employees fail to include on their tax returns. See U.S. General Accounting Office, TAX GaP 29-30 (GAO/GGD-94-I 23, I994). 
The EITC also presents a second potential problem: collection of overpayments. EITC noncompliance may result in overpayments that are large relative to the taxpayers' income but that are small dollar amounts in absolute terms (no more than $\$ 3370$ per taxpayer). ${ }^{209}$ Several thousand dollars can be an attractive windfall for an individual but is a relatively small amount for the IRS to seek to collect from one person, particularly if investigation and collection require audit rather than computerized correspondence. The IRS might rationally choose to focus on higher-return cases, ${ }^{210}$ particularly given the difficulty of actually recovering the money from low-income households.

Current estimates of noncompliance in the EITC program are widely cited but probably flawed. In I990, Congress received IRS data showing that ineligible taxpayers received thirty-nine percent of EITC benefits paid in $1985 .{ }^{211}$ These data sparked newspaper reports and congressional concern, but the IRS methodology may have exaggerated error rates. ${ }^{212}$ In response to the EITC's perceived problem of EITC noncompliance, the 1990 amendments to the EITC took steps to improve compliance. ${ }^{213}$ Anecdotal evidence continues to provoke con-

Other underreporting - of self-employment income, for example - is more difficult to detect. See id. at 15 .

209 See supra pp. 541-42 and accompanying table and graph. Total dollar amounts at stake would be greater in large-scale, coordinated fraud schemes.

210 See, e.g., Fewer People Get Stung by IRS Audits, New IRS Statistics Show, Wall St. J., June 8 , I994, at AI (reporting that the IRS now audits less than one percent of individual tax returns).

211 See Spencer Rich, For Working Poor, a Tough Program to Figure, WASH. Post, Aug. I4, I990, at Arg; Spencer Rich, IRS: $40 \%$ of Recipients Of Child Aid Ineligible, WaSh. Post, June 22, I990, at Aro.

212 The source of the data was the 1985 Taxpayer Compliance Measurement Program (TCMP), drawn from a comprehensive audit of 50,000 taxpayers conducted every three years. In a TCMP audit, which occurs several years after the filing of the original return, taxpayers are required to provide verification for every item claimed. Failure to provide verification results in a determination that the taxpayer was ineligible for the claimed benefit. Thus, some EITC recipients classified as ineligible in the TCMP audit may have been eligible but simply could not satisfy the exacting verification requirements, particularly after the fact. Cf. Tim Gray, Child Care Conferees Aim to Tackle Compliance Problems with EITC, 48 TAX NoTES 259, 260 (1990) (reporting the response of one critic of reports of noncompliance in the EITC, who characterized the IRS data as 'soft stuff' and noted that the TCMP counts failure to respond to IRS queries as noncompliance). Liebman and Eissa found that only ${ }_{13} \%$ of taxpayers with EITC benefits disallowed by the TCMP in 1988 had adjusted gross incomes outside the EITC eligibility range. See Jeffrey B. Liebman \& Nada Eissa, Noncompliance and the Earned Income Tax Credit: Taxpayer Error or Taxpayer Fraud?, tbl. 4.6 (Dec. I993) (unpublished manuscript, on file with the Harvard Law School Library).

213 See Holtzblatt, supra note $\mathrm{I} 3 \mathrm{I}$, at $\mathrm{I} 80$. EITC errors revealed in the TCMP data were correlated with mistakes in filing status and dependency claims, see id., and raised the possibility that many low-income families claimed the EITC if they lived with their children, unaware that the receipt of significant transfer payments would render them ineligible. The 1990 Act reforms in the EITC, described in Holtzblatt's article, reflected Congress's intention to simplify eligibility and verification requirements. See id. at 185 . Whether the 1990 reforms are effective in reducing the EITC error rate can be determined only by data on EITC compliance after 1990 . 
cern about noncompliance in the EITC, however. ${ }^{214}$ In addition, regardless of actual magnitudes of noncompliance and enforcement problems, a few highly publicized incidents could erode support for the program. ${ }^{215}$

Once again, however, the goal of tax-transfer integration may constrain policy responses to the trade off between compliance and participation. Measures to improve compliance with the EITC may require special rules that deviate from those of the federal income tax, and the resulting breach in tax-transfer integration could lower participation. For example, in 1990, congressional concern about noncompliance in the EITC led to the adoption of rules intended to simplify eligibility criteria and improve verification. ${ }^{216}$ These deviations from the federal income tax rules meant, however, that filing a tax return was no longer enough to receive the EITC. Under the I990 rules, an EITC claimant must also complete a separate (and somewhat complex) schedule. ${ }^{217}$ Some analysts have argued that the 1990 changes should be repealed because requiring extra information from claimants discourages participation. ${ }^{218}$

Should the EITC's apparently unconventional balance between participation and compliance warrant concern? If errors are largely inadvertent and technical and the ineligible beneficiaries are poor, noncompliance may be of relatively little concern. Fraudulent claims and errors that benefit better-off groups would likely provoke greater concern. But supporters of the EITC's work incentive features might

The reported EITC error rates are much higher than the error rates reported for traditional transfers. In 1989 , for example, the overpayment rate for AFDC was $5.7 \%$, for Food Stamps $7.3 \%$, and for SSI $3.4 \%$. See 1993 GREEN Book, supra note I0, at 1596 . Holtzblatt notes that the TCMP estimates of EITC error rates are "high but not unique" for tax provisions: although wage and salary income is underreported by only $3.6 \%$, non-wage income is underreported by $35 \%$. Holtzblatt, supra note $I_{3} \mathrm{I}$, at 183 . However, data on welfare error rates have also been heavily criticized on methodological grounds and may not be directly comparable to measured EITC error rates. For critiques of quality control statistics, see BRODKIN, cited above in note I $_{3}$, at 4I-57; From Quality Control to Quality Improvement in AFDC and Medicaid II 3-37 (Fredrica D. Kramer ed., I988); and William H. Simon, Legality, Bureaucracy, and Class in the Welfare System, 92 YALE L.J. I198, $1207-13$ (1983).

214 See Patrick Kissane, Tax Credit for Poor Is Widely Abused, N.Y. Times, Aug. I0, I993, at AI8; Ronald Sullivan, Four Charged in Tax Plot for Refunds, N.Y. TimEs, Feb. 17, 1994, at B3. The IRS has acknowledged the problem of EITC fraud. See Yin, Scholz, Forman \& Mazur, supra note I3I, at 249 n.86. For an account of IRS mistakes, see Albert B. Crenshaw, IRS Mistakenly Sends Checks to Unentitled, WASH. Post, Mar. 13, 1992, at DI, which reported that, in an attempt to insure that eligible taxpayers receive the EITC, the IRS mistakenly sent checks to taxpayers who deliberately did not claim the EITC because they were not entitled to it.

215 The publication of the 1985 TCMP data, which revealed EITC noncompliance, in 1985 created an uproar that was soothed by congressional enactment of EITC reforms in 1990 .

216 See Holtzblatt, supra note $\mathrm{I} 3 \mathrm{I}$, at $\mathrm{I} 85$.

217 See H.R. REP. No. 964, rorst Cong., 2d Sess. 1038 (1990).

218 See Yin, Scholz, Forman \& Mazur, supra note $\mathrm{I}_{3} \mathrm{I}$, at 26I-62 (suggesting elimination of Schedule EIC and slight modification of the tax return in order to increase participation). 
oppose the award of any benefits to nonworkers, even if they are poor. Moreover, even technical noncompliance violates the intended terms of the program and creates inequities between compliant and noncompliant participants. Unfortunately, in the absence of current and more detailed data, we cannot know which groups are benefitting from noncompliance. ${ }^{219}$

Although some policy makers may be willing to accept noncompliance in the EITC as the price of obtaining its advantages, the potential for noncompliance inherent in a tax-based program is likely to be a matter of recurring public concern. The strong negative public and political reaction to EITC error rates reported in $1990^{220}$ and more recent criticisms of EITC fraud ${ }^{221}$ suggest that persuading policymakers to accept noncompliance as a cost of tax-based administration may not be easy.

\section{CONClusions and Directions for Further Research}

This Article raises serious questions about the validity of the oversimplified claims made for - and against - the EITC. Claims that the EITC promotes work and responsibility are exaggerated, but EITC opponents' attempts to equate the EITC with welfare are equally unsound. The EITC may have certain advantages as a taxbased program, including greater accessibility, cheaper administration, and reduced stigma for recipients. But policy analysts should also consider the inherent disadvantages of a tax-based program: less accurate targeting, less responsiveness to changing needs, and vulnerability to noncompliance. Although the magnitude of these costs requires empirical study, they are qualitatively important. Legislation in the I990s has transformed the EITC into a major income support program without acknowledging that tax-based administration imposes these potentially significant institutional constraints.

Understanding these trade offs does not require a rejection of the EITC or tax-based administration. The challenge for EITC advocates is to strengthen the case for the EITC by acknowledging these limitations and then explaining why the EITC is still worthwhile. A full evaluation of the appropriate role for the EITC and tax-based administration in American social welfare policy is beyond the scope of this Article. Future research could extend the analysis begun here to compare more fully the strengths and weaknesses of the EITC with those

219 Cf. Liebman \& Eissa, supra note 2 1 2, tbl. 4.6 (suggesting that 1988 TCMP data shows that only $13 \%$ of ineligible EITC claimants had adjusted gross incomes above the EITC income cutoff). These findings, however, may be outdated in light of the significant changes in the EITC program since 1988 .

220 See supra notes $2 \mathrm{I} \mathrm{I}-2 \mathrm{I} 3$ and accompanying text.

221 See, e.g., Bovard, supra note 12, at AI8 (characterizing the EITC as a "gravy train for con artists"). 
of existing alternative institutions and potential new programs - for example, family allowances or wage subsidies - each of which might be tax-based or administered through traditional expenditure programs.

Empirical studies could provide crucial evidence about the practical importance of the institutional constraints facing the EITC and other tax-based programs both in absolute terms and relative to existing welfare programs or other alternative policies. They might, in addition, provide aggregate measures for comparing programs, which would facilitate evaluation of, for example, the relative inaccuracy of the EITC attributable to mismeasurement of income and the family unit and to noncompliance. Ideal data also would reveal how sensitive these institutional limitations are to changes in the size and design of the program. ${ }^{222}$ Unfortunately, good data on the current EITC program are likely to be scarce until the middle or late $1990{ }^{223}$ In the meantime, policymakers will have to rely on anecdotal evidence and a priori analysis, both of which suggest that the EITC should not be overutilized.

Additional studies of EITC administration may reveal other important considerations in evaluating and designing tax-based transfer programs. For example, if commercial tax preparers play a significant role as intermediaries between EITC recipients and the government, ${ }^{224}$ policy analysts should investigate the performance of these privately paid EITC "case workers." The cost of return preparation, although paid by EITC recipients, is properly viewed as a hidden administrative cost of the EITC program. Perhaps these preparers offer a productive way to use private markets to improve social service delivery, but the fees they charge in effect reduce net EITC benefits received. Expanding free return-preparation services and educating EITC recipients to prepare their own returns may be an appropriate policy response.

A more sophisticated approach to tax-transfer integration would acknowledge the shortcomings of tax-based transfer programs and would attempt to create alternative institutions that incorporate the

222 This description is, of course, a lawyer's wish-list and not a pragmatic research proposal. Limitations on data and research design may well constrain the empirical information that can realistically be collected.

223 Data collected before I99 I reflect the characteristics of a much smaller program. See supra note 203 and accompanying text. Data collected between I99I and I 993 will reflect a somewhat larger program but may be distorted by the transition to new eligibility rules enacted in I 990 , see supra note 213 and accompanying text, and the complex "supplemental" credits enacted in 1990 and repealed in 1993, see Omnibus Budget Reconciliation Act of 1993, Pub. L. No. 103-66, § I3 I31, I07 Stat. 312, 433-35 (I993) (codified at I.R.C. § 32 (Supp. V I993)); I.R.C. \$32(b)(I)(D), (b)(2) (Supp. V 1993). Post-I993 data will be more reliable, but the expanded program will not be fully phased in until calendar year I996. See I.R.C. \$32(a).

224 See supra note 123. 
best features of tax and welfare administration and are stronger than either standing alone. For example, traditional administrative structures could conceivably implement at least some of the desirable reforms embodied by the EITC. ${ }^{225}$ Other possible avenues for progress include improved information-sharing between the tax system and transfer programs or greater coordination of facilities and personnel. ${ }^{226}$ A few states have begun to experiment with such administrative coordination..$^{227}$

My own long-term project has two principal goals. First, it will expand the analysis begun in this Article to consider comparative institutional features of a wider variety of redistributive programs. For example, this Article focuses primarily on programs that tailor benefits explicitly to economic need. One additional issue is how the trade offs identified here change in the context of non-income-tested programs, which appear to differ significantly in their political appeal, revenue cost, distributional patterns and efficiency costs. Second, it will seek to develop a normative framework for evaluating different redistributive programs - attempting to identify the norms that should guide us in evaluating social welfare policy and determining how to strike a balance among competing policy goals. A central issue for the project remains the extent to which tax-based programs and tax policy can play a productive role in social welfare policy.

My next Article will consider current "family policy" proposals. For many years, commentators have argued that the United States, like many Western European countries, should fund an array of government programs to redistribute resources to families. These proposals typically include income transfers and public financing for child care. In recent years, American policy analysts have called for family allowances, ${ }^{228}$ child support assurance programs, ${ }^{229}$ and increased gov-

225 For example, negative income tax plans typically sought to adopt many of the legal structures and procedures of the federal income tax, but there was no consensus on whether they should actually be administered through the federal income tax system. See GreEN, supra note 6, at I II-I 2, I66-68; SURREY, supra note 97, at 312-13.

226 The Clinton administration's welfare reform bill permits several demonstration projects in which states may administer EITC advance payments through the welfare system. See S. 2224 , ro3d Cong., 2d Sess. \$741, reprinted in I40 Cong. REC. S73 I 2-I3 (daily ed. June 21, I994).

227 For example, Michigan has applied for a waiver for a welfare demonstration that would administer EITC advance payments through the AFDC and food stamp delivery system. See Scholz, supra note 105, at I, 7-8. Minnesota is studying the possibility of integrating its tax-credit and traditional transfer programs by using the transfer system. See Wilson \& Cline, supra note 155 , at $670-75$.

228 See, e.g., Yin, Scholz, Forman \& Mazur, supra note I3I, at 283-86 (proposing a similar "family allowance benefit"); George K. Yin \& Jonathan B. Forman, Redesigning the Earned Income Tax Credit Program to Provide More Effective Assistance to the Working Poor, 59 TAx NotES 95 I, 959-60 (I993) (suggesting a refundable tax credit based on family size).

229 See, e.g., IRwin Garfinkel, Assuring Child Support 47-56 (I992) (suggesting that the government pay child support if support from nonresident parents is inadequate); HAVEMAN, 
ernment aid for child care. ${ }^{230}$ Traditional scholarship on taxation of the family focuses primarily on the rules governing the tax liability of married couples and the adjustment of tax liability for family size..$^{231}$ My project will move beyond these topics to consider whether taxbased programs and the tax system's administrative structure can usefully further the goals of social welfare and family policy.

supra note 122 , at I $_{63}-65$ (suggesting that public transfers should make up the difference between an absent parent's support and a set minimum level). The Clinton administration's welfare reform bill contains a child support assurance demonstration project. See S. 2224 , 103d Cong., 2d Sess. §681, reprinted in 140 CONG. REC. S7304-05 (daily ed. June 2 I, I994); I40 Cong. REC. $\mathrm{S}_{7348-62}$ (describing proposed child support assurance measures).

230 See, e.g., National Comm'n on Children, Beyond Rhetoric: A New American Agenda for Children AND Families 65-79 (I99I) (advocating governmental support for child care programs).

231 See, e.g., Gann, supra note 108, at 3-4 (arguing that it is more equitable to tax married individuals separately than jointly); McCaffery, supra note 104, at 987-88 (arguing that the taxation of married couples helps perpetuate traditional gender roles). 